\title{
Nitrification and its oxygen consumption along the turbid Chang Jiang River plume
}

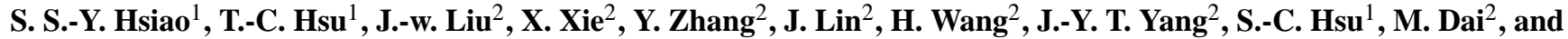 \\ S.-J. Kao ${ }^{1,2}$ \\ ${ }^{1}$ Earth System Science Program, Taiwan International Graduate Program, Research Center for Environmental Changes, \\ Academia Sinica, Taipei, Taiwan \\ ${ }^{2}$ State Key Laboratory of Marine Environmental Science, Xiamen University, Xiamen, China
}

Correspondence to: S.-J. Kao (sjkao@gate.sinica.edu.tw)

Received: 30 March 2013 - Published in Biogeosciences Discuss.: 24 May 2013

Revised: 30 January 2014 - Accepted: 23 February 2014 - Published: 14 April 2014

\begin{abstract}
Nitrification is a series of processes that oxidizes ammonia to nitrate, which contributes to hypoxia development in coastal oceans, especially in eutrophicated regions. The nitrification rate of bulk water $\left(\mathrm{NR}_{\mathrm{b}}\right)$ and particle free water $\left(\mathrm{NR}_{\mathrm{pf}}\right.$, particle $>3 \mu \mathrm{m}$ eliminated) were determined along the Chang Jiang River plume in August 2011 by nitrogen isotope tracer technique. Measurements of dissolved oxygen (DO), community respiration rate (CR), nutrients, dissolved organic nitrogen (DON), total suspended matter (TSM), particulate organic carbon/nitrogen (POC/ PON), acid-leachable iron and manganese on suspended particles and both archaeal and $\beta$-proteobacterial ammonia monooxygenase subunit A gene ( $a m o \mathrm{~A})$ abundance on size-fractioned particles ( $>3 \mu \mathrm{m}$ and $0.22-3 \mu \mathrm{m}$ ) were conducted. The $\mathrm{NR}_{\mathrm{b}}$ ranged from undetectable up to $4.6 \mu \mathrm{mol} \mathrm{L}^{-1} \mathrm{day}^{-1}$, peaking at a salinity of $\sim 29$. $\mathrm{NR}_{\mathrm{b}}$ values were positively correlated with ammonium concentration, suggesting the importance of substrate in nitrification. In the river mouth and the inner plume, $\mathrm{NR}_{\mathrm{b}}$ was much higher than $\mathrm{NR}_{\mathrm{pf}}$, indicating that the nitrifying microorganism is mainly particle associated, which was supported by its significant correlation with amoA gene abundance and TSM concentration. The estimated oxygen demands of nitrification accounted for 0.32 to $318 \%$ of $\mathrm{CR}$, in which $50 \%$ samples demanded more oxygen than that predicted by by the Redfield model (23\%), indicating that oxygen might not be the sole oxidant though DO was sufficient ( $>58 \mu \mathrm{mol} \mathrm{kg}-1$ ) throughout the observation period. The excess nitrification-associated oxygen demand (NOD) showed a tendency to occur at lower DO samples accompanied by higher acid-leachable Fe/Mn, which implied reac-
\end{abstract}

tive $\mathrm{Fe}^{3+} / \mathrm{Mn}^{4+}$ may play a role as oxidant in the nitrification process. Stoichiometric calculation suggested that reactive $\mathrm{Fe}$ on particles was 10 times the oxidant demand required to complete ammonia oxidation in the entire plume. The potential involvement of reactive iron and manganese in the nitrification process in oxygenated water further complicated nitrogen cycling in the turbid river plume.

\section{Introduction}

Estuaries and coastal seas receiving natural and anthropogenic materials from rivers serve as an important reactor for chemical/physical transformation. A growing population and human activities in the past few decades have enhanced riverine nutrient loads more than 5 -fold, which has profoundly impacted the aquatic environment of the land-ocean boundary (Dai et al., 2011; Howarth and Marino, 2006). Nitrogen is one of the most influential elements among the enhanced nutrients (Galloway et al., 2004; Gunnarsson et al., 2000; Howarth and Marino, 2006) that may lead to eutrophication. Subsequently promoting the oxygen consumption may result in more severe hypoxia or a "dead zone" which disrupts estuarine and coastal ecosystems (Rabalais et al., 2002; Smith et al., 2006; Galloway et al., 2004; Ravishankara et al., 2009). The original nitrogen cycle is thus altered as environmental conditions change.

One of the processes most affected is nitrification, in which ammonia is oxidized to nitrate. Nitrification is composed of two steps, i.e., ammonia oxidation and nitrite 
oxidation. Ammonia oxidation is carried out by ammoniaoxidizing archaea (AOA) and ammonia-oxidizing bacteria $(\mathrm{AOB})$, while nitrite oxidation is performed by nitriteoxidizing bacteria (NOB). Ammonia oxidation requires three-quarters of the oxidant demand in nitrification and produces nitrous oxide, a greenhouse gas, as a byproduct. Anthropogenic-enhanced nitrification becomes an important oxygen consuming process contributing to the establishment of hypoxia. In a British Columbia fjord (Grundle and Juniper, 2011), the Delaware River (Lipschultz et al., 1986), the Pearl River (Dai et al., 2008), Narragansett Bay (Berounsky and Nixon, 1993) and the Schelde estuary (Gazeau et al., 2005 ), nitrification constituted $20-30 \%$ of the total oxygen consumption, and even up to $64 \%$ in the Mississippi River estuary (Pakulski et al., 1995). In addition, the exacerbated nitrification may also contribute to alkalinity consumption that consequently enhances ocean acidification (Hu and Cai, 2011). In spite of its importance having been highlighted, knowledge about nitrification in the land-ocean boundary remains incomplete.

Recent culture-based and field experiments in freshwater and marine upwelling systems revealed that both ammonia and nitrite oxidizers tend to attach to particles where ammonium adsorption may occur to stimulate nitrification (Xia et al., 2009; Wang et al., 2010; Fussel et al., 2012). One distinctive feature of Asian rivers is that enhanced nutrient fluxes are often accompanied by huge amounts of suspended sediments sourced from soil erosion (Syvitski et al., 2005; Milliman and Syvitski, 1992), resulting in highly turbid coastal and shelf water (e.g., the East China Sea shelf satellite images in Fig. 1a). Previous field studies in the Seine and in the Schelde estuary observed a positive relation between total suspended matter (TSM) concentration and nitrification potential based on nutrient monitoring and model calculation (Brion et al., 2000; Andersson et al., 2006). To our knowledge only one single paper has implemented direct measurements of nitrification rates on particulate fraction in an estuary (Berounsky and Nixon, 1993); however, its results in Narragansett Bay with low suspended particle concentration did not support the importance of particles for nitrification.

In this study, we selected the East China Sea shelf, which receives remarkable inputs of nutrient and sediment from the Chang Jiang River, whose water and sediment discharge are the third and the fourth largest, respectively, in the world (Milliman and Syvitski, 1992; Syvitski et al., 2005). The annual suspended sediment discharge is ca. $400 \mathrm{Mt} \mathrm{yr}^{-1}$ (Chen et al., 2001), though decreasing since the Three Gorges Dam construction. Presently, the annual load of dissolved inorganic nitrogen (DIN) is $\sim 10.8 \times 10^{10}\left(\right.$ mole yr $\left.^{-1}\right)$, which is eight times higher than that observed in 1960 (Wang, 2009; Chai et al., 2009). Meanwhile, summer hypoxia was first reported in 1959 in the plume region, and it has expanded eastward with a rising nutrient load since then (Wang, 2009; Ning et al., 2011; Zhu et al., 2011; Wang et al., 2012).
In the Chang Jiang plume, the interplay of nitrogenous nutrient and suspended sediment in nitrification has never been investigated; results would be particularly interesting with regard to the summer high flow which brings with it great particulate organic matter and nutrient input that might trigger hypoxia. Our cruise took place during flood season to explore the fractional contribution of nitrification in community oxygen consumption off the Chang Jiang River estuary. We hypothesized that (1) the enhanced supply of suspended particles during flood provides micro-niches on the surface of particles, which absorb ammonium that provides substrate for the nitrifier to facilitate nitrification, and (2) besides oxygen, redox-sensitive elements, such as iron and manganese might also act as electron acceptors for nitrification. This is the first investigation that uses the stable isotope tracer method for particle-associated nitrification in the river plume which leads to highly turbid shelf water that is common in Asian marginal seas. The purpose of this study is to explore the biogeochemical relations between oxygen, nitrification and redox-sensitive elements in a stoichiometric way.

\section{Materials and methods}

\subsection{Sampling}

Our cruise was conducted from 15 to 24 August 2011, one week after Typhoon Muifa passed through the East China Sea (6-7 August; see trajectory in Fig. 1a). Apparently, Muifa disturbed the water column off the Chang Jiang River mouth.

Water samples were collected along two offshore transects starting from the river mouths of Chang Jiang and Qiantang River toward the shelf (Fig. 1b). The sampling sites were classified into three zones, including river mouth, inner plume and outer plume, based on salinity difference and geographical features (Fig. 1b). Those stations with a salinity lower than 20 were classified as river mouth. The most offshore stations, Y4 and Y5, were classified as outer plume where they are influenced by the warm and saline Taiwan warm current (Wang, 2009; Zhou et al., 2009). The other stations with a salinity of 20 to 28 were classified as inner plume. In total, 12 stations were monitored in this study. A turbidity front appeared at the salinity of $\sim 22$ (see Tseng et al., 2014, for spatial distribution of TSM), and the distinctive correlations between TSM and the nitrification rate of those stations support our zonal classification (see below). Meanwhile, from the temperature distribution (see Tseng et al., this issue) we know that the upwelling had occurred and outcropped at the seaward side of the turbidity front. In fact, most of the inner plume stations were located in the upwelling zone. We also repeated our sampling three times at station Y3 on 15, 19 and 22 August (designated 1Y3, 2Y3 and $3 Y 3$, respectively).

The water discharge data collected at the upstream gauging station (Fig. 1c) was examined to check whether Typhoon 

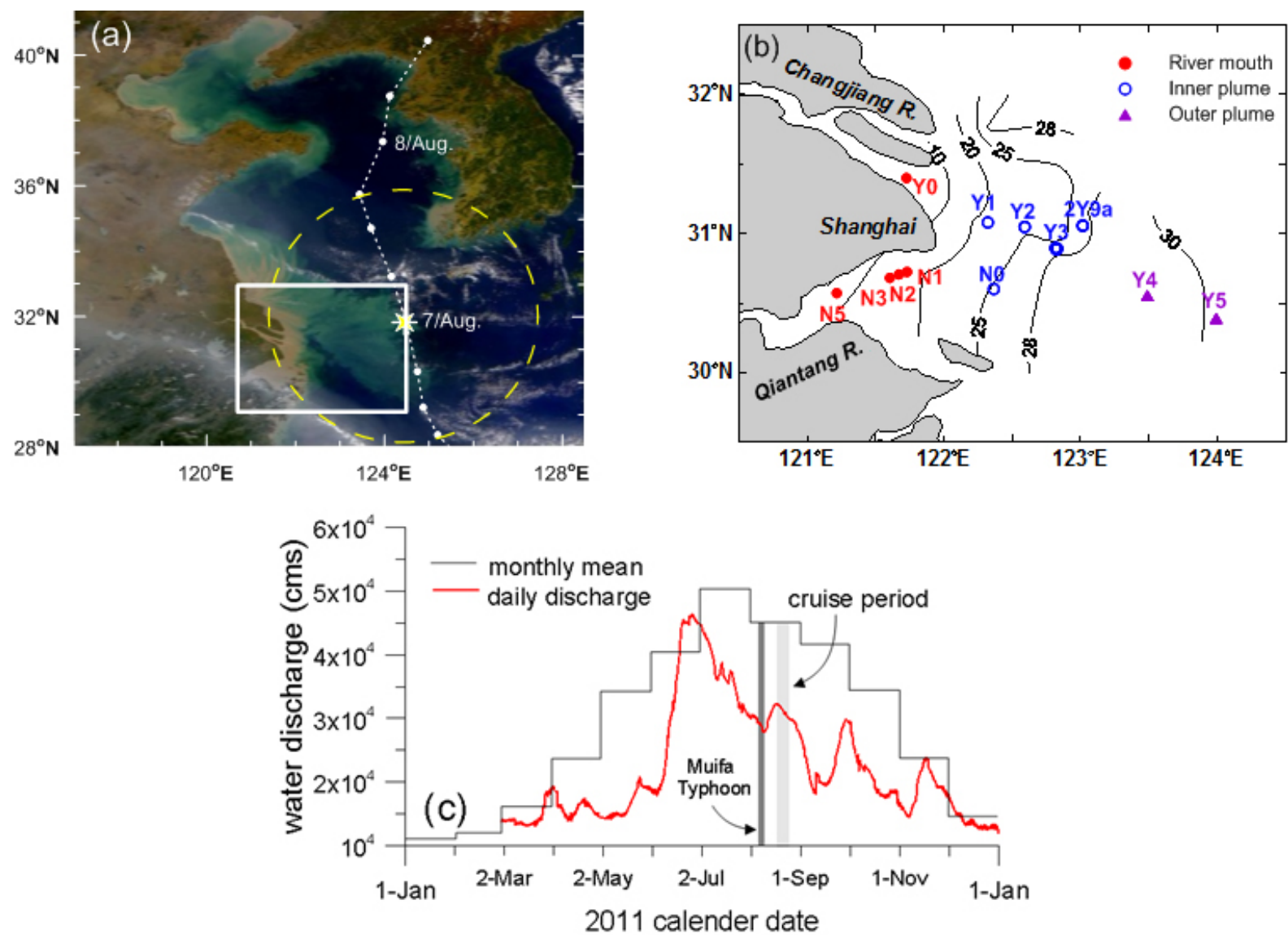

Fig. 1. (a) Satellite image of the Yellow Sea, the Bo Hai and the East China Sea. Note that turbid water is found in the coastal zone and the river mouths. The white rectangle represents our study site. The white dashed line is the trajectory of Muifa, and the yellow dashed circle indicates cloud coverage of Muifa (average wind speed $>14 \mathrm{~m} \mathrm{~s}^{-1}$ ) at 0.00 a.m. UTC $+8,7$ August. (b) Map of sampling stations. Contours stand for the sea surface salinity. The sampling stations are classified as river mouth $(\bullet)$, inner plume (०) and outer plume ( $\Delta)$. Station names are marked. (c) The long-term monthly mean water discharge (solid gray) and daily discharge (red curve) at Datong, the most downstream gauge of the Chang Jiang River. Dark gray bar represents the period influenced by Typhoon Muifa and light gray stands for the cruise period.

Muifa had induced an unusually high water discharge. However, the water discharge during the cruise period was in the range of historical discharge patterns of summer. Obviously, in such a large watershed, Typhoon Muifa was not strong enough to increase the water discharge significantly. Therefore our cruise was still representative of the summer highflow condition.

\subsection{Hydrographical and chemical data}

Vertical profiles of salinity, temperature and dissolved oxygen were obtained by conductivity-temperature-depth (CTD) profiling system (SBE 911, SeaBird Co.). The CTD-derived dissolved oxygen data were calibrated using discrete measurements by using the Winkler method.

Water samples were collected with $12 \mathrm{~L}$ Niskin bottles in order to determine dissolved oxygen, nutrients, TSM, particulate organic carbon/nitrogen and acid-leachable metals.
The nutrient samples were all analyzed on deck. Ammonium was analyzed by the indophenol blue spectrophotometric method (Pai et al., 2001). Nitrite and nitrate were measured using the AA3 system (Dai et al., 2011). The detection limits for ammonium, nitrite and nitrate were $0.16,0.02$ and $0.07 \mu \mathrm{mol} \mathrm{L}-1$, respectively. TSM samples were collected by filtering $1 \sim 4 \mathrm{~L}$ of water sample through $47 \mathrm{~mm}$ precombusted Whatman GF/F filters. These glass fiber filters were further analyzed for particulate organic carbon/nitrogen (POC/PON) by the elemental analyzer detailed in Kao et al. (2012). Dissolved organic nitrogen (DON) was filtered through a $47 \mathrm{~mm}$ polycarbonate membrane with $0.2 \mu \mathrm{m}$ pore size and analyzed by the persulfate oxidation method (Bronk et al., 2000) with a detection limit of $0.6 \mu \mathrm{mol} \mathrm{L}^{-1}$. Acidleachable metal on TSM samples was collected by filtering $0.25 \sim 1 \mathrm{~L}$ of water through a $47 \mathrm{~mm}$ acid-washed polycarbonate membrane with $0.45 \mu \mathrm{m}$ pore size. The filters were extracted by using $1 \mathrm{~N}$ hydrochloric acid for $16 \mathrm{~h}$ (Kao et al., 2004) in a test tube and then centrifuged; the acid extract 
was further analyzed by inductively coupled plasma mass spectrometry (ICP-MS) (Hsu et al., 2004). The detection limits for $\mathrm{Mn}, \mathrm{Fe}$ and $\mathrm{Al}$ were $0.89,139$ and $60 \mu \mathrm{g} \mathrm{L}{ }^{-1}$, which were 2 orders of magnitude below the measured concentration. Using the sequential extraction method by Huertadiaz and Morse (1990), the reactive fraction of metal could be extracted from $1 \mathrm{~N}$ hydrochloric acid from a particulate sample. For this reason, we considered those $1 \mathrm{~N} \mathrm{HCl}$-leachable $\mathrm{Al}, \mathrm{Fe}$ and $\mathrm{Mn}$ as operationally defined reactive $\mathrm{Al}, \mathrm{Fe}$ and $\mathrm{Mn}$. Hereafter, $\mathrm{Fe}$ (III) and $\mathrm{Mn}$ (IV) represent $\mathrm{Fe}^{3+}$ or $\mathrm{Mn}^{4+}$ oxide and $\mathrm{HCl}-\mathrm{Fe}, \mathrm{HCl}-\mathrm{Mn}$ stand for reactive $\mathrm{Fe}$ and reactive $\mathrm{Mn}$, respectively.

\subsection{Incubation experiments}

Nitrification rate (NR) was measured by means of the stable isotopic tracer method (Lipschultz et al., 1986). For bulk nitrification rate $\left(\mathrm{NR}_{\mathrm{b}}\right)$, six $250 \mathrm{~mL}$ narrow-necked gas-tight glass bottles were overflowed with more than twice their volume and sealed without any headspace after adding ${ }^{15} \mathrm{NH}_{4} \mathrm{Cl}$ to a final concentration of $50 \mathrm{nmol} \mathrm{L}^{-1}$ to each bottle. They were placed for 3, 6 and $12 \mathrm{~h}$ dark incubation (duplicate) in a darkened $50 \mathrm{~L}$ tank fixed on deck. A submersible water pump provided surface seawater continuously to maintain the incubation temperature. The incubation bottles were fixed upside down in a stainless steel rack immersed in the tank. The control sample was immediately filtered without incubation through a $47 \mathrm{~mm} 0.22 \mu \mathrm{m}$ polycarbonate membrane and stored in a freezer. All incubations were terminated by filtering through a $0.22 \mu \mathrm{m}$ polycarbonate membrane, and the filtrate was stored frozen at $-20^{\circ} \mathrm{C}$ until laboratory analysis.

The change of ${ }^{15} \mathrm{~N}$ content in nitrate plus nitrite pool which was the product of ammonia oxidation and nitrite oxidation was determined by applying the denitrifier method (Casciotti et al., 2002; Sigman et al., 2001). The regression coefficient of the time course curves of ${ }^{15} \mathrm{~N}$ content in nitrate plus nitrite pool for all measurements was greater than 0.8 (not shown). Similar steps were implemented for the incubation of the particle-free nitrification rate $\left(\mathrm{NR}_{\mathrm{pf}}\right)$ after removing particles by using a $3 \mu \mathrm{m}$ polycarbonate membrane (Berounsky and Nixon, 1993). $\mathrm{NR}_{\mathrm{pf}}$ was conducted only for selected stations (Y0, Y3, 2Y3 and Y5).

The natural nitrification rate was calculated by the following Eq. (1):

$R_{\mathrm{NO}_{\mathrm{x}}}=\frac{\mathrm{d}\left[{ }^{15} \mathrm{~N}\right]}{\mathrm{d} t} \times \frac{\left[{ }^{14} \mathrm{NH}_{4}^{+}\right]+\left[{ }^{15} \mathrm{NH}_{4}^{+}\right]}{\left[{ }^{15} \mathrm{NH}_{4}^{+}\right]}$,

where $R_{\mathrm{NO}_{\mathrm{x}}}$ is the nitrification rate, $t$ is the incubation time, $\left[{ }^{15} \mathrm{~N}\right]$ is the concentration of ${ }^{15} \mathrm{~N}$ in nitrate plus nitrite pool in the sample, and $\left[{ }^{14} \mathrm{NH}_{4}^{+}\right]$and $\left[{ }^{15} \mathrm{NH}_{4}^{+}\right]$are the observed natural ammonium concentration and artificial addition of stable isotopic tracer $\left({ }^{15} \mathrm{NH}_{4}^{+}\right)$, respectively. We used the term $\mathrm{NO}_{\mathrm{x}}$ since both $\mathrm{NO}_{3}^{-}$and $\mathrm{NO}_{2}^{-}$were measured by applying the denitrifier method.
The community respiration rate (CR) was determined by the decrement in dissolved oxygen content after $24 \mathrm{~h}$ of incubation in darkness. Sampled water was aliquot in duplicate $100 \mathrm{mLDO}$ bottles fully covered by aluminum foil, and all bottles were submerged in the same tank described above with surface seawater circulation. The difference in $\mathrm{O}_{2}$ concentration between the initial and the dark treatment was used to compute the CR.

\subsection{Archaeal and $\beta$-proteobacterial functional gene abundance}

Particulate-associated gene abundance of archaeal and $\beta$ proteobacterial ammonia monooxygenase (amoA) were determined using the quantitative polymerase chain reaction (qPCR) method described in Hu et al. (2011). 1-2 L seawater samples were first filtered through a $47 \mathrm{~mm} 3 \mu \mathrm{m}$ polycarbonate filter to collect the size fractions of $>3 \mu \mathrm{m}$. Then the filtrate was further filtered through a $47 \mathrm{~mm} 0.22 \mu \mathrm{m}$ polycarbonate filter for the size fractions of $0.22-3 \mu \mathrm{m}$. All polycarbonate membranes were kept frozen at $-80^{\circ} \mathrm{C}$ until laboratory analysis.

\section{Results}

\subsection{Distribution of hydrographic and chemical parameters}

\subsubsection{Salinity and DO}

Our sampling transects crossed salinity values of 0.2 to 34.3 along the Chang Jiang River plume (Fig. 2a) and the Qiantang River mouth (Fig. 3a). The dissolved oxygen over these transects ranged from 58 up to $225 \mu \mathrm{mol} \mathrm{L}^{-1}$ (Figs. $2 \mathrm{~b}$ and $3 \mathrm{~b}$ ). Only the bottom water of station $2 \mathrm{Y} 9 \mathrm{a}$ reached the threshold of hypoxia. The hypoxic area of this cruise (Liu et al., unpublished data of this cruise) was smaller compared to historical records (Wei et al., 2007; Zhu et al., 2011). This was likely due to the disturbance by Typhoon Muifa.

\subsubsection{Dissolved inorganic and organic nitrogen}

Distribution of ammonium (Fig. 2c), nitrite (Fig. 2d), nitrate (Fig. 2e) and DON (Fig. 2f) along the plume transect showed distinctive patterns. The distributions of nitrate and DON resembled the salinity pattern. The highest concentration of nitrate $\left(133 \mu \mathrm{mol} \mathrm{L}^{-1}\right)$ and DON $\left(27 \mu \mathrm{mol} \mathrm{L}^{-1}\right)$ appeared at station Y0 where salinity was the lowest. However, the distribution of ammonium and nitrite exhibited a biologically mediated pattern. The maximum ammonium $\left(2.0 \mu \mathrm{mol} \mathrm{L}^{-1}\right)$ occurred at $10 \mathrm{~m}$ depth at the offshore station Y5 while the maximum amount of nitrite $\left(1.0 \mu \mathrm{mol} \mathrm{L}^{-1}\right)$ appeared right below it at $20 \mathrm{~m}$ depth. A secondary maximum of ammonium $\left(1.2 \mu \mathrm{mol} \mathrm{L}{ }^{-1}\right)$ occurred at the bottom of the nearshore station $\mathrm{Y} 2$, which coexisted with the highest $\mathrm{NR}_{\mathrm{b}}$ (see below). 

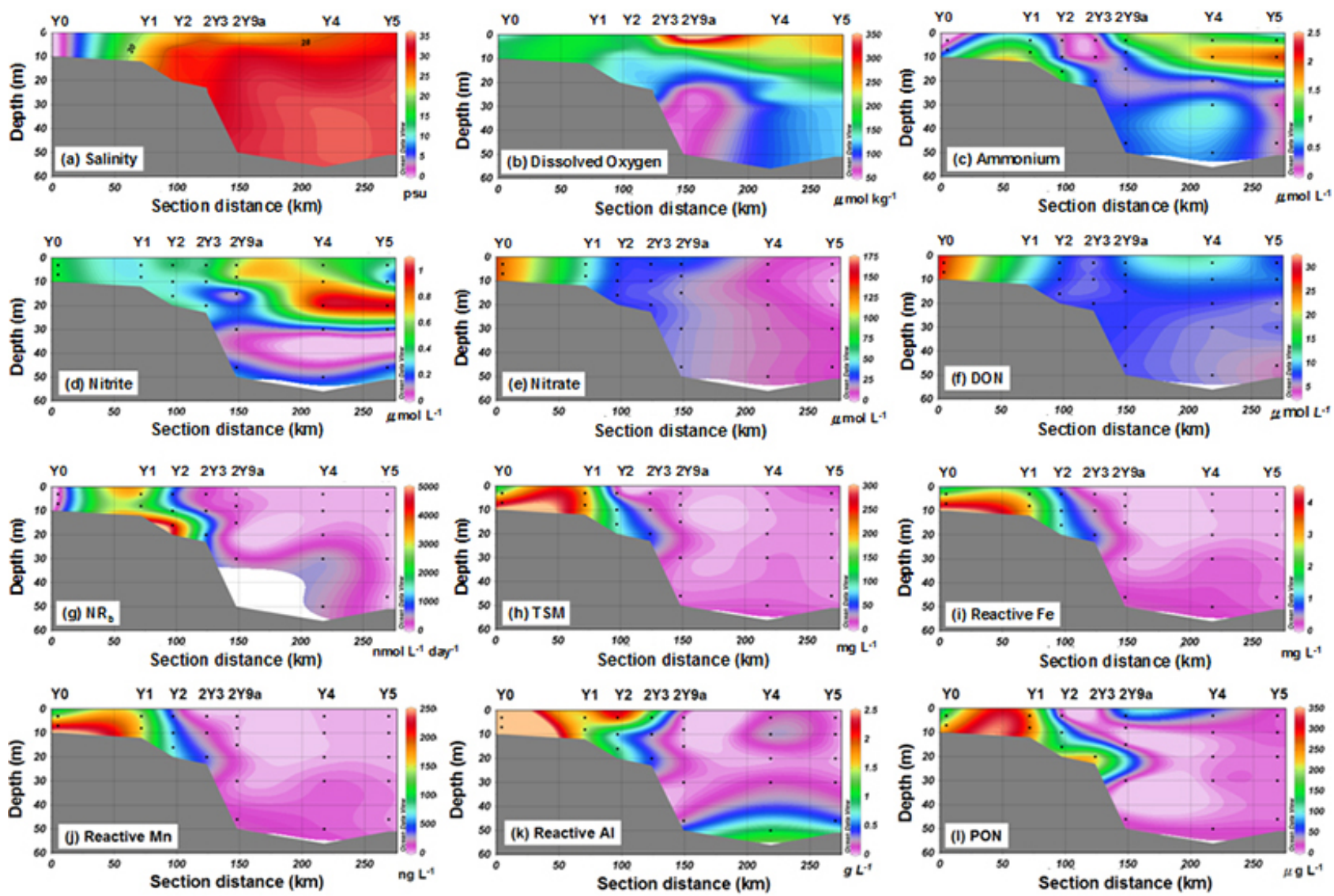

Fig. 2. Transects of (a) salinity, (b) dissolved oxygen, (c) ammonium, (d) nitrite, (e) nitrate, (f) dissolved organic nitrogen (DON), (g) bulk nitrification rate $\left(\mathrm{NR}_{\mathrm{b}}\right)$, (h) total suspended material (TSM), (i) reactive $\mathrm{Fe}$, (j) reactive $\mathrm{Mn}$, (k) reactive $\mathrm{Al}$, (l) and particulate organic nitrogen (PON) across the Chang Jiang plume. Salinity and dissolved oxygen were obtained continuously by CTD. Discrete sampling depths of other parameters are indicated by black dots. Data were plotted using the DIVA gridding in ocean data view v.4.3.2 (http://odv.awi.de, 2010).

In the Qiantang River mouth, ammonium and nitrite were less than 1.0 and $0.2 \mu \mathrm{mol} \mathrm{L}^{-1}$, respectively (Fig. $3 \mathrm{c}$ and d). Nitrate ranged from 86.7 to $149 \mu \mathrm{molL}^{-1}$ (Fig. 3e) while DON ranged from 7.35 to $17.8 \mu \mathrm{mol} \mathrm{L}^{-1}$ (not shown as transect because of limited measurements). Both nitrate (Fig. 3e) and DON were high in the freshwater end, similar to the results of the Chang Jiang transect.

\subsubsection{Suspended particles}

TSM ranged over 2 orders of magnitude from 2.6$244 \mathrm{~m} \mathrm{~L}^{-1}$ along the Chang Jiang plume (Fig. 2h). TSM in the Qiantang River mouth (Fig. 3h) ranged from 1150 to $3000 \mathrm{mg} \mathrm{L}^{-1}$, which is 1 order higher than the Chang Jiang River mouth due to intensive wave and tidal mixing. For other particulate-associated acid-leachable metals, such as $\mathrm{Al}, \mathrm{Fe}$ and $\mathrm{Mn}$, similar seaward decreasing patterns can be seen (Figs. 2i-k and 3i-k). These acid-leachable metals showed $\sim 3$ orders of magnitude variability in concentration. The percentage of acid-leachable metal on TSM ranged from
0.2 to $17.3 \%(w / w)$ for $\mathrm{Al}$, from 0.1 to $5.7 \%(w / w)$ for $\mathrm{Fe}$ and from 0.03 to $2.5 \%(w / w)$ for Mn (data not shown). The concentrations of POC (not shown) and PON (Figs. $2 \mathrm{j}$ and 3f) also had a wide range over more than 3 orders of magnitude. By contrast, the range of organic $\mathrm{C} / \mathrm{N}$ ratio (4.7-6.6) was very narrow, indicating the particulate organic matter was mainly marine sourced (Lamb et al., 2006).

\subsection{Correlation between $\mathrm{NR}_{\mathrm{b}}$, nitrogenous nutrient and TSM}

The $\mathrm{NR}_{\mathrm{b}}$ along the plume peaked at intermediate salinity and gradually decreased seaward until it was undetectable in the near-surface water at the most offshore station. The maximum $\mathrm{NR}_{\mathrm{b}}\left(4.6 \mu \mathrm{mol} \mathrm{L}^{-1}\right.$ day $\left.^{-1}\right)$ occurred near the bottom of station Y2 $(S=29)$ (Fig. $2 \mathrm{~g})$. The second largest $\mathrm{NR}_{\mathrm{b}}$ $\left(2.0 \mu \mathrm{mol} \mathrm{L}^{-1} \mathrm{day}^{-1}\right)$ occurred at station N5 $(S=9.4)$ in the Qiantang River mouth (Fig. 3g). The $\mathrm{NR}_{\mathrm{b}}$ in the Qiantang River mouth ranged from 210 to $2000 \mathrm{nmol} \mathrm{L}^{-1} \mathrm{day}^{-1}$, 

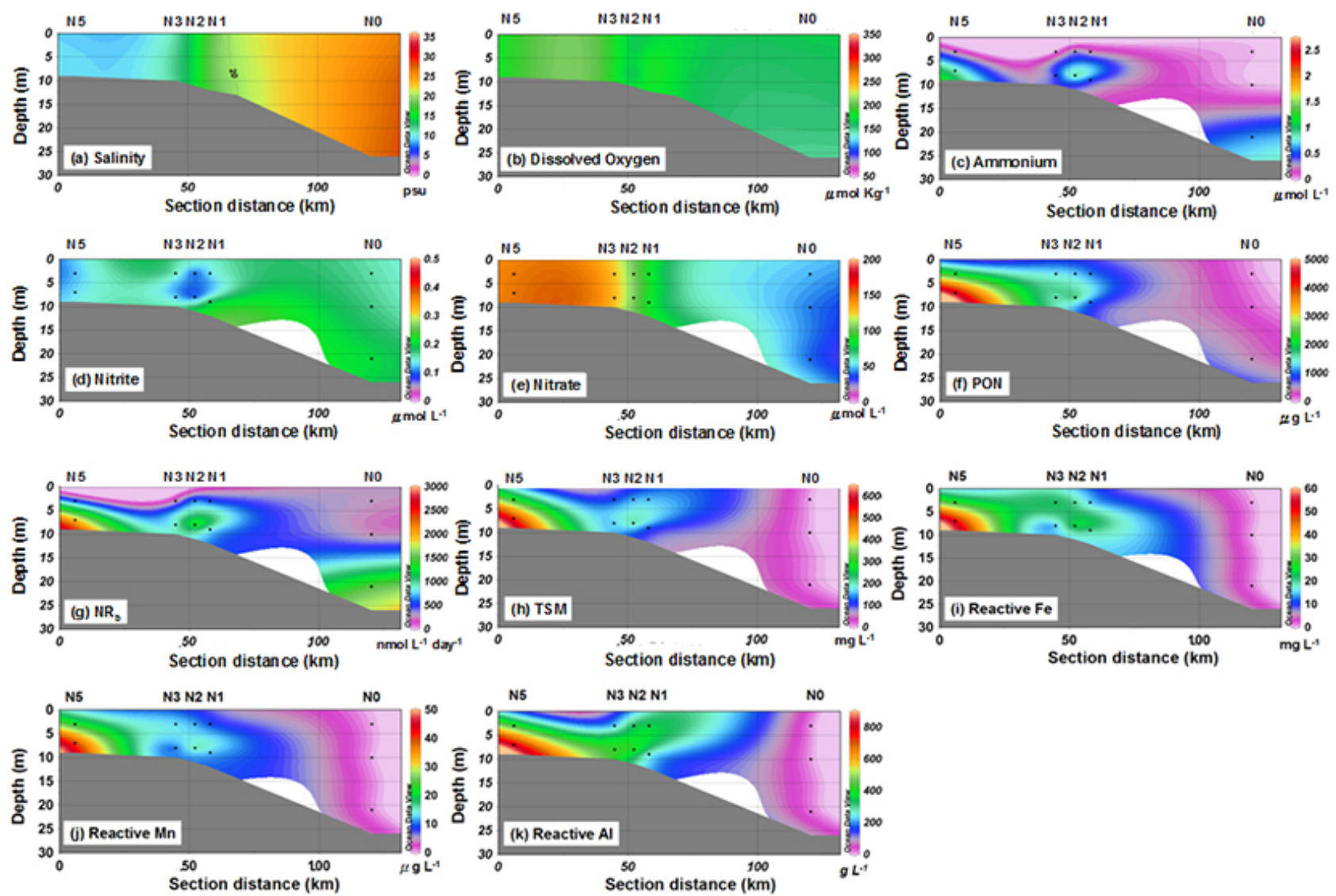

Fig. 3. Transects of (a) salinity, (b) dissolved oxygen, (c) ammonium, (d) nitrite, (e) nitrate, (f) particulate organic nitrogen (PON), (g) bulk nitrification rate $\left(\mathrm{NR}_{\mathrm{b}}\right)$, (h) total suspended material(TSM), (i) reactive $\mathrm{Fe}$, (j) reactive $\mathrm{Mn}$, (k) and reactive $\mathrm{Al}$ across the Qiantang river mouth. The color mapping represents the same range of data as in Fig. 2 except for PON, TSM and reactive Fe. Salinity and dissolved oxygen were obtained continuously by CTD. Discrete sampling depths of other parameters are indicated by black dots. Data were plotted using the DIVA gridding in ocean data view v.4.3.2 (http://odv.awi.de, 2010).

which was overall higher than that in the Chang Jiang River mouth.

Significant positive linear correlations between $\mathrm{NR}_{\mathrm{b}}$ and ammonium were found in the inner plume and the river mouth (Fig. 4a) and the two correlations were almost identical. In fact, only two surface water samples in the outer plume, which contained the highest ammonium but lowest $\mathrm{NR}_{\mathrm{b}}$, deviated from the regression. As for TSM (Fig. 4b), distinctive correlations between $\mathrm{NR}_{\mathrm{b}}$ and TSM occurred in the inner plume ( slope $=13.2$, intercept $=238$ ) and the river mouth (slope $=0.33$, intercept $=92$ ); yet, in the outer plume TSM is too low to reveal any correlation with $\mathrm{NR}_{\mathrm{b}}$. For the river mouth and the inner plume, all particulate-associated parameters including $\mathrm{POC}, \mathrm{PON}$ and reactive $\mathrm{Al} / \mathrm{Fe} / \mathrm{Mn}$ possessed a similar pattern as TSM did with regard to $\mathrm{NR}_{\mathrm{b}}$, and the statistic value of these linear regressions is listed in Table 2. The most significant linear correlation was found between $\mathrm{NR}_{\mathrm{b}}$ and reactive $\mathrm{Mn}$ in the inner plume $(n=26$, $R^{2}=0.5407, p=0.0025$ ). However, since we do not have solid evidence indicating that $\mathrm{Mn}$ directly participated in ni- trification, reactive Mn may just covary with other parameters associated with TSM, such as adsorbed ammonium.

As for DON, except for the river mouth where the DON range was wide and demonstrated a negative correlation with $\mathrm{NR}_{\mathrm{b}}$ (Table 2a), no positive correlation can be found between DON $\left(5-8 \mu \mathrm{mol} \mathrm{L}^{-1}\right)$ and $\mathrm{NR}_{\mathrm{b}}$ for the inner and the outer plume .

\subsection{Community respiration}

The $\mathrm{CR}$ values ranged from 1.21$\sim 10.79 \mu \mathrm{mol} \mathrm{O}_{2} \mathrm{~L}^{-1}$ day $^{-1}$ along the Chang Jiang River transect. Unfortunately, CR in the Qiantang River mouth was not analyzed due to extremely high turbidity. Having put all the CR data together, we could see a positive linear correlation between ammonium and CR (Table 2d), which indicated that oxygen consumption due to aerobic degradation of organic matter might be a major source of ammonium. 


\subsection{The nitrification rate and the amo $\mathrm{A}$ abundance}

We combined the result of particulate-associated gene abundance of archaeal and $\beta$-proteobacterial amoA with $\mathrm{NR}_{\mathrm{b}}$ and $\mathrm{NR}_{\mathrm{pf}}$ in Table 1. Both archaeal and $\beta$-proteobacterial amoA abundance strongly decreased seaward. Compared to those in the outer plume, both amoA abundance and $\mathrm{NR}_{\mathrm{b}}$ were $1-$ 2 orders of magnitude higher in the turbid river mouth and inner plume. Since $98 \%$ of amoA was present on larger particle $(>3 \mu \mathrm{m})$ fractions, and $\mathrm{NR}_{\mathrm{pf}}$ occupied less than half of $\mathrm{NR}_{\mathrm{b}}$ in the river mouth and the inner plume, it suggested that ammonia oxidation is more likely to occur on larger particles $(>3 \mu \mathrm{m})$ along the plume. By contrast, much larger fractions of $\beta$-proteobacterial amoA ( $>62 \%$ ) and archaeal amoA (> 83\%) were found in the size fraction of $0.22-3 \mu \mathrm{m}$ in the subsurface at station Y3 and station Y5. In relatively clear water stations, the $\mathrm{NR}_{\mathrm{pf}}$ was almost identical and even higher than $\mathrm{NR}_{\mathrm{b}}$. (This will be discussed in Sect. 4.1.3)

\section{Discussion}

\subsection{The interplay of nitrogenous nutrient and TSM in nitrification}

\subsubsection{Ammonium}

From the perspective of substrate supply, the distribution of $\mathrm{NR}_{\mathrm{b}}$ should be limited by ammonium and oxygen concentration. The observed positive correlation between $\mathrm{NR}_{\mathrm{b}}$ and ammonium concentration (Fig. 4a) indicates that ammonium may play an important role in nitrification in the inner plume and the river mouth where oxygen is sufficient. The range of $\mathrm{NR}_{\mathrm{b}}\left(0-4.6 \mu \mathrm{mol} \mathrm{L}^{-1} \mathrm{~d}^{-1}\right)$ along the Chang Jiang River plume was similar to that of the Rhône River plume (0$4.2 \mu \mathrm{mol} \mathrm{L}^{-1} \mathrm{~d}^{-1}$; Bianchi et al., 1999) and Tamar estuary (0-3 $\mu \mathrm{mol} \mathrm{L}^{-1} \mathrm{~d}^{-1}$; Owens, 1986); the ammonium concentration of all those areas was less than $3 \mu \mathrm{mol} \mathrm{L}^{-1}$ lower. However, our $\mathrm{NR}_{\mathrm{b}}$ is lower when compared to the Mississippi River estuary (up to $13.4 \mu \mathrm{mol} \mathrm{L}^{-1} \mathrm{~d}^{-1}$; Pakulski et al., 1995), Schelde Estuary (up to $16.8 \mu \mathrm{mol} \mathrm{L}^{-1} \mathrm{~d}^{-1}$; Somville, 1984; Andersson et al., 2006), Narragansett Bay (up to $11.0 \mu \mathrm{mol} \mathrm{L}^{-1} \mathrm{~d}^{-1}$; Berounsky and Nixon, 1993) and Pearl River estuary (up to $12.5 \mu \mathrm{mol} \mathrm{L}^{-1} \mathrm{~d}^{-1}$; Dai et al., 2008). Higher $\mathrm{NR}_{\mathrm{b}}$ in those estuaries is likely caused by higher ammonium concentration $\left(>3 \mu \mathrm{mol} \mathrm{L}^{-1}\right)$, which again reveals the importance of ammonia supply. However, some non-measured factors might play a role, such as that reported for a cold British Columbia fjord where ammonium concentration was higher $\left(0-5 \mu \mathrm{mol} \mathrm{L}{ }^{-1}\right)$ but $\mathrm{NR}_{\mathrm{b}}$ was lower $(0.32-$ $0.48 \mu \mathrm{mol} \mathrm{L}^{-1} \mathrm{~d}^{-1}$ ) (Grundle and Juniper, 2011).

On the other hand, in the outer plume the highest ammonium with the lowest $\mathrm{NR}_{\mathrm{b}}$ appeared in the subsurface at station $\mathrm{Y} 5$. The unexpectedly low $\mathrm{NR}_{\mathrm{b}}$ under high substrate availability was probably due to photoinhibition (Mackey et
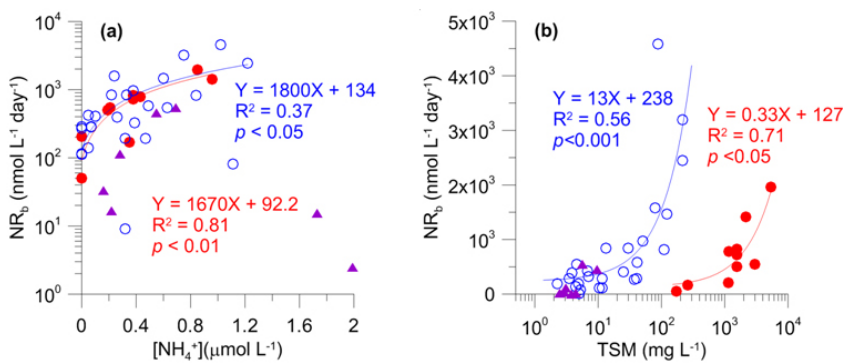

Fig. 4. Scatter plot of bulk ammonia oxidation rate against (a) ammonium, and (b) TSM along the Chang Jiang River plume and the Qiantang River mouth. The symbols indicate the data from the river mouth $(\bullet)$, inner plume $(\circ)$, or outer plume $(\boldsymbol{\Delta})$. The blue and red curves indicate the linear regression in $\log -\log$ scale for the inner plume and the river mouth, respectively. Linear regression line for all data points is shown. Note that the $X$ axis in (a) and $Y$ axis in (b) are in $\log _{10}$ scale.

al., 2011; Merbt et al., 2012) in the relatively clear surface seawater.

\subsubsection{Dissolved organic nitrogen}

Dissolved organic nitrogen (DON) was thought to be an important substrate in the upper open ocean for remineralization (Knapp et al., 2011) and subsequent nitrification. However, no positive correlation was observed between $\mathrm{NR}_{\mathrm{b}}$ and $\mathrm{DON}$ implying that either DON was not an important source of the supply of substrate for nitrification or that the labile DON with high turnover rate occupies a small fraction of DON in our study area. By contrast, $\mathrm{PON}$ was well correlated to $\mathrm{NR}_{\mathrm{b}}$ implying PON has greater potential for providing ammonia for nitrification.

\subsubsection{Suspended particles}

The gene abundance of archaeal and $\beta$-proteobacterial amoA on both $>3 \mu \mathrm{m}$ and $0.22-3 \mu \mathrm{m}$ fractions showed that archaeal ammonia oxidizers were dominant along the Chang Jiang River plume (Table 1). Both archaeal and $\beta$-proteobacterial ammonia oxidizers preferred to inhabit $>3 \mu \mathrm{m}$ particulate fractions in the samples with higher TSM or lower oxygen saturation, such as the turbid river mouth and the bottom of the inner plume. This result may imply that the heterotrophic degradation of particulate organic matter is the potential source of ammonia for nitrifiers to form a biofilm and develop their population (Belser, 1979). Conversely, the outer plume and the near-surface water of the inner plume contained much less TSM $\left(2.4-10.5 \mathrm{mg} \mathrm{L}^{-1}\right)$ and higher oxygen saturation nitrifiers were found to be abundant in $0.22-3 \mu \mathrm{m}$ fraction. This may result from the fact that particle organic matter was no longer the dominant source of ammonium in this region. High oxygen saturation values occurred in this region and may also suggest that particles may 
Table 1. Particulate-associated archaeal and $\beta$-proteobacterial amoA copies and the nitrification rate in bulk versus filtered water for three stations along the Chang Jiang River plume.

\begin{tabular}{|c|c|c|c|c|c|c|c|c|c|c|}
\hline \multirow{2}{*}{$\begin{array}{l}\text { Loca- } \\
\text { tion }\end{array}$} & \multirow{2}{*}{$\begin{array}{l}\text { Sta- } \\
\text { tion }\end{array}$} & \multirow[b]{2}{*}{$\begin{array}{l}\text { Depth } \\
\text { (m) }\end{array}$} & \multirow[b]{2}{*}{$\begin{array}{r}\text { TSM } \\
(\mathrm{mg} \\
\left.\mathrm{L}^{-1}\right)\end{array}$} & \multirow{2}{*}{$\begin{array}{r}\text { DO } \\
\text { satu- } \\
\text { ration }\end{array}$} & \multicolumn{2}{|c|}{ Nitrification rate } & \multicolumn{2}{|c|}{$\beta$-proteobacterial amoA } & \multicolumn{2}{|c|}{ Archaeal amoA } \\
\hline & & & & & $\begin{array}{r}\text { Bulk* }^{*} \\
\left(\mathrm{nmol} \mathrm{L}^{-1}\right. \\
\left.\text { day }^{-1}\right)\end{array}$ & $\begin{array}{r}\text { Filtered }^{* *} \\
\left(\mathrm{nmol} \mathrm{L}^{-1}\right. \\
\left.\text { day }^{-1}\right)\end{array}$ & $\begin{array}{r}\text { Part. } \\
(>3 \mu \mathrm{m})^{* * *} \\
\left(\text { copy } \mathrm{L}^{-1}\right)\end{array}$ & $\begin{array}{r}\text { Part. } \\
(0.22-3 \mu \mathrm{m})^{* * *} \\
\left.(\operatorname{copy~L})^{-1}\right)\end{array}$ & $\begin{array}{r}\text { Part. } \\
(>3 \mu \mathrm{m})^{* * *} \\
\left(\text { copy } \mathrm{L}^{-1}\right)\end{array}$ & $\begin{array}{r}\text { Part. } \\
(0.22-3 \mu \mathrm{m})^{* * *} \\
\left(\text { copy L }{ }^{-1}\right)\end{array}$ \\
\hline \multirow[t]{2}{*}{$\begin{array}{l}\text { River } \\
\text { mouth }\end{array}$} & \multirow[t]{2}{*}{ Y0 } & 7 & 261.0 & $80.4 \%$ & $168.23 \pm 0.02$ & $18.87 \pm 0.04$ & $\begin{array}{r}1.44 \times 10^{6} \pm \\
4.01 \times 10^{5} \\
(99 \%)\end{array}$ & $\begin{array}{r}1.20 \times 10^{4} \pm \\
1.03 \times 10^{3} \\
(1 \%)\end{array}$ & $\begin{array}{r}2.56 \times 10^{7} \pm \\
6.40 \times 10^{6} \\
(66 \%)\end{array}$ & $\begin{array}{r}1.35 \times 10^{7} \pm \\
1.61 \times 10^{7} \\
(34 \%)\end{array}$ \\
\hline & & 3 & 170.2 & $80.3 \%$ & $49.97 \pm 0.02$ & $9.29 \pm 0.01$ & $\begin{array}{r}2.19 \times 10^{5} \pm \\
8.16 \times 10^{4} \\
(98 \%)\end{array}$ & $\begin{array}{r}5.13 \times 10^{3} \pm \\
6.69 \times 10^{2} \\
(2 \%)\end{array}$ & $\begin{array}{r}1.65 \times 10^{8} \pm \\
2.54 \times 10^{6} \\
(100 \%)\end{array}$ & $\begin{array}{r}5.73 \times 10^{5} \pm \\
2.45 \times 10^{4} \\
(0 \%)\end{array}$ \\
\hline \multirow{3}{*}{$\begin{array}{l}\text { Inner } \\
\text { plume }\end{array}$} & \multirow[t]{3}{*}{ Y3 } & 21 & 111.1 & $56.9 \%$ & $818.59 \pm 0.36$ & $22.40 \pm 2.15$ & - & - & - & - \\
\hline & & 10 & 41.1 & $64.2 \%$ & $578.64 \pm 0.25$ & $28.81 \pm 0.25$ & - & - & - & - \\
\hline & & 3 & 4.6 & $100.8 \%$ & $543.05 \pm 0.19$ & $798.01 \pm 0.34$ & $\begin{array}{r}5.64 \times 10^{4} \pm \\
6.26 \times 10^{3} \\
(95 \%)\end{array}$ & $\begin{array}{r}2.86 \times 10^{3} \pm \\
2.78 \times 10^{2} \\
(5 \%)\end{array}$ & $\begin{array}{r}6.38 \times 10^{3} \pm \\
1.79 \times 10^{3} \\
(1 \%)\end{array}$ & $\begin{array}{r}4.62 \times 10^{5} \pm \\
7.96 \times 10^{3} \\
(99 \%)\end{array}$ \\
\hline \multirow[t]{3}{*}{$\begin{array}{l}\text { Inner } \\
\text { plume }\end{array}$} & \multirow[t]{3}{*}{$2 \mathrm{Y} 3$} & 20 & 48.1 & $53.0 \%$ & $973.25 \pm 0.73$ & $71.15 \pm 0.05$ & $\begin{array}{r}4.79 \times 10^{5} \pm \\
3.00 \times 10^{4} \\
(100 \%)\end{array}$ & $\begin{array}{r}2.20 \times 10^{3} \pm \\
7.65 \times 10^{2} \\
(0 \%)\end{array}$ & $\begin{array}{r}1.50 \times 10^{8} \pm \\
3.40 \times 10^{6} \\
(100 \%)\end{array}$ & $\begin{array}{r}1.10 \times 10^{5} \pm \\
2.80 \times 10^{4} \\
(0 \%)\end{array}$ \\
\hline & & 10 & 22.1 & $61.8 \%$ & $408.28 \pm 0.37$ & $215.09 \pm 0.02$ & - & - & - & - \\
\hline & & 3 & 9.2 & $82.5 \%$ & $283.50 \pm 0.11$ & $152.97 \pm 0.02$ & - & - & - & - \\
\hline \multirow[t]{5}{*}{$\begin{array}{l}\text { Outer } \\
\text { plume }\end{array}$} & \multirow[t]{5}{*}{ Y5 } & 46 & 4.5 & $59.6 \%$ & $16.75 \pm 0.01$ & $73.60 \pm 0.01$ & $\begin{array}{r}9.55 \times 10^{3} \pm \\
2.04 \times 10^{3} \\
(38 \%)\end{array}$ & $\begin{array}{r}1.55 \times 10^{4} \pm \\
7.29 \times 10^{2} \\
(62 \%)\end{array}$ & $\begin{array}{r}2.70 \times 10^{6} \pm \\
2.60 \times 10^{5} \\
(2 \%)\end{array}$ & $\begin{array}{r}1.40 \times 10^{8} \pm \\
2.60 \times 10^{6} \\
(98 \%)\end{array}$ \\
\hline & & 30 & 3.0 & $60.3 \%$ & 32.8 & 44.6 & - & - & - & - \\
\hline & & 20 & 3.0 & $77.6 \%$ & $\mathrm{BDL}$ & 7.8 & - & - & - & - \\
\hline & & 10 & 3.8 & $92.7 \%$ & 2.5 & 2.5 & - & - & - & - \\
\hline & & 3 & 10.5 & $119.2 \%$ & BDL & BDL & BDL & $\begin{array}{r}6.87 \times 10^{2} \pm \\
7.36 \times 10^{0}\end{array}$ & $\begin{array}{r}1.40 \times 10^{4} \pm \\
2.80 \times 10^{3} \\
(16 \%)\end{array}$ & $\begin{array}{r}7.20 \times 10^{4} \pm \\
3.30 \times 10^{3} \\
(84 \%)\end{array}$ \\
\hline
\end{tabular}

be composed of more grazers or primary producers competing for ammonia.

The positive correlation between TSM and nitrification has been addressed in freshwater systems (Xia et al., 2009; Wang et al., 2010) and in the relatively turbid region of estuaries, where nitrification activities were found to be higher (Berounsky et al., 1993, Helder and Devries, 1983), especially in the zone of estuarine turbidity maxima (Owens, 1986). Moreover, a similar correlation was found in the oxygen minimum zone (Woebken et al., 2007; Galand et al., 2008) though the particulate organic matter (POM) concentration was much lower.

To our knowledge, we are the first to report such distinctive correlations between $\mathrm{NR}_{\mathrm{b}}$ and TSM (Fig. 4b) observed along the salinity gradient in the river plume, and the slope of the linear regression for the river mouth was $1 / 40$ that of the inner plume. Since the PON content (\%) on TSM (which can be derived from Fig. $2 \mathrm{~h}$ and $\mathrm{j}$ ) was significantly higher for the inner plume than the river mouth ( $p=0.0046$, unpaired $t$ test), we suspected that enriched PON can provide ammonia more efficiently. The variation in regression slopes in one single estuary was likely controlled by specific surface areas, which further determines the amount of organics and bacteria being driven by dynamic energy to sustain particle suspension. Combined with the fractional distribution of amoA abundance and NR on suspended particles, we may conclude that the ammonia oxidizer was mainly particulate associated. The particulate-attaching preference of ammonia oxidizers has also been reported in microscopic observation in many coastal seas (Phillips et al., 1999; Bano et al., 2000; Hollibaugh et al., 2002; Freitag and Prosser, 2004; O’Mullan and Ward, 2005; Wuchter et al., 2006).

Note that we also found a significant negative correlation between reactive $\mathrm{Fe}$ and nitrite in the river mouth and the outer plume (Tables $2 \mathrm{a}, 2 \mathrm{c}$ ) though the causes are not clear. Previous studies reported that the nitrite oxidoreductase required for nitrite oxidation contains at least four Fe-S clusters, suggesting a high Fe demand for this process (Kirstein and Bock, 1993; Off et al., 2010; Santoro et al., 2013). 
Table 2a. Correlation matrix of field-surveyed data in the river mouth of the Chang Jiang River plume.

\begin{tabular}{|c|c|c|c|c|c|c|c|c|c|c|c|c|c|c|c|}
\hline Unit & $\begin{array}{r}\text { Temp. } \\
{ }^{\circ} \mathrm{C}\end{array}$ & Sal. & $\begin{array}{c}\mathrm{NH}_{4}^{+} \\
\mu \mathrm{mol} \\
\mathrm{L}^{-1}\end{array}$ & $\begin{array}{c}\mathrm{NO}_{3}^{-} \\
\mu \mathrm{mol} \\
\mathrm{L}^{-1}\end{array}$ & $\begin{array}{c}\mathrm{NO}_{2}^{-} \\
\mu \mathrm{mol} \\
\mathrm{L}^{-1}\end{array}$ & $\begin{array}{r}\mathrm{NR}_{\mathrm{b}} \\
\mathrm{nmol} \mathrm{L}^{-1} \\
\mathrm{day}^{-1}\end{array}$ & $\begin{array}{r}\text { DO } \\
\mu \mathrm{mol} \\
\mathrm{kg}^{-1}\end{array}$ & $\begin{array}{r}\text { TSM } \\
\text { mg } \\
\mathrm{L}^{-1}\end{array}$ & $\begin{array}{r}\text { CR } \\
\mu \mathrm{mol} \mathrm{L}^{-1} \\
\text { day }^{-1}\end{array}$ & $\begin{array}{r}\text { POC } \\
\mu \mathrm{g} \\
\mathrm{L}^{-1}\end{array}$ & $\begin{array}{r}\mathrm{PON} \\
\mu \mathrm{g} \\
\mathrm{L}^{-1}\end{array}$ & $\begin{array}{r}\mathrm{HCl}^{-\mathrm{Al}^{\dagger}} \\
\mathrm{g} \\
\mathrm{L}^{-1}\end{array}$ & $\begin{array}{r}\mathrm{HCl}-\mathrm{Fe}^{\dagger} \\
\mathrm{mg} \\
\mathrm{L}^{-1}\end{array}$ & $\begin{array}{r}\mathrm{HCl}-\mathrm{Mn}^{\dagger} \\
\mathrm{ng} \\
\mathrm{L}^{-1}\end{array}$ & $\begin{array}{r}\mathrm{DON} \\
\mu \mathrm{mol} \\
\mathrm{L}^{-1}\end{array}$ \\
\hline$n$ & 10 & 10 & 10 & 10 & 10 & 10 & 10 & 10 & 2 & 10 & 10 & 10 & 10 & 10 & 6 \\
\hline Temp. & 1 & & & & & & & & & & & & & & \\
\hline Sal. & $-0.752^{*}$ & 1 & & & & & & & & & & & & & \\
\hline$\left[\mathrm{NH}_{4}^{+}\right]$ & & & 1 & & & & & & & & & & & & \\
\hline$\left[\mathrm{NO}_{3}^{-}\right]$ & $0.984^{* *}$ & $-0.688^{*}$ & & 1 & & & & & & & & & & & \\
\hline$\left[\mathrm{NO}_{2}^{-}\right]$ & & $-0.847^{*}$ & & & 1 & & & & & & & & & & \\
\hline $\mathrm{NR}_{\mathrm{b}}$ & & & $0.902^{*}$ & & & 1 & & & & & & & & & \\
\hline DO & $0.673^{*}$ & $-0.654^{*}$ & & $0.638^{*}$ & & & 1 & & & & & & & & \\
\hline TSM & & & & & & $0.845^{* *}$ & & 1 & & & & & & & \\
\hline CR & & & & & & & & & 1 & & & & & & \\
\hline POC & & & & & & $0.845^{* *}$ & & $0.988 * *$ & & 1 & & & & & \\
\hline PON & & & & & & $0.853^{* *}$ & & $0.986^{* *}$ & & $1.000^{* * *}$ & 1 & & & & \\
\hline $\mathrm{HCl}-\mathrm{Al}^{\dagger}$ & & & $0.664^{*}$ & & $-0.708^{*}$ & $0.896^{* * *}$ & & $0.959 * *$ & & $0.954 * *$ & $0.956^{* * *}$ & 1 & & & \\
\hline $\mathrm{HCl}-\mathrm{Fe}^{\dagger}$ & & & $0.660^{*}$ & & $-0.669 *$ & $0.893 * *$ & & $0.983^{* *}$ & & $0.977 * *$ & $0.977 * *$ & $0.994 * *$ & 1 & & \\
\hline $\mathrm{HCl}-\mathrm{Mn}^{\dagger}$ & & & & & & $0.842 * *$ & & $0.999 * *$ & & $0.991 * *$ & $0.989 * *$ & $0.964 * *$ & $0.986^{* *}$ & 1 & \\
\hline DON & & $-0.857^{*}$ & & & $0.876^{*}$ & & & & & $-0.857 *$ & $-0.863^{*}$ & $-0.839^{*}$ & $-0.834^{*}$ & & 1 \\
\hline
\end{tabular}

$n$ is sample number. The other numbers are the Pearson's correlation coefficient of two by two parameters.

$*$ indicates $p<0.05$ and $* *$ indicates $p<0.01$.

$\dagger \mathrm{HCl}-\mathrm{Al}, \mathrm{HCl}-\mathrm{Fe}$ and $\mathrm{HCl}-\mathrm{Mn}$ respectively indicate reactive Al, reactive Fe and reactive Mn which were extracted from suspended particles by $1 \mathrm{~N} \mathrm{HCl}$. The method is described in Sect. 2.2 .

Table 2b. Correlation matrix of field-surveyed data in the inner plume of the Chang Jiang River plume.

\begin{tabular}{|c|c|c|c|c|c|c|c|c|c|c|c|c|c|c|c|}
\hline Unit & $\begin{array}{r}\text { Temp. } \\
{ }^{\circ} \mathrm{C}\end{array}$ & Sal. & $\begin{array}{r}{\left[\mathrm{NH}_{4}^{+}\right]} \\
\mu \mathrm{mol} \\
\mathrm{L}^{-1}\end{array}$ & $\begin{array}{r}\left.\mathrm{NO}_{3}^{-}\right] \\
\mu \mathrm{mol} \\
\mathrm{L}^{-1}\end{array}$ & $\begin{array}{r}{\left[\mathrm{NO}_{2}^{-}\right]} \\
\mu \mathrm{mol} \\
\mathrm{L}^{-1}\end{array}$ & $\begin{array}{r}\mathrm{NR}_{\mathrm{b}} \\
\mathrm{nmol}^{-1} \\
\mathrm{day}^{-1}\end{array}$ & $\begin{array}{r}\text { DO } \\
\mu \mathrm{mol} \\
\mathrm{kg}^{-1}\end{array}$ & $\begin{array}{r}\text { TSM } \\
\mathrm{mg} \\
\mathrm{L}^{-1}\end{array}$ & $\begin{array}{r}\text { CR } \\
\mu \mathrm{mol} \mathrm{L}^{-1} \\
\text { day }^{-1}\end{array}$ & $\begin{array}{r}\text { POC } \\
\mu \mathrm{g} \\
\mathrm{L}^{-1}\end{array}$ & $\begin{array}{r}\text { PON } \\
\mu g \\
L^{-1}\end{array}$ & $\begin{array}{r}\mathrm{HCl}-\mathrm{Al}^{\dagger} \\
\mathrm{g} \\
\mathrm{L}^{-1}\end{array}$ & $\begin{array}{r}\mathrm{HCl}-\mathrm{Fe}^{\dagger} \\
\mathrm{mg} \\
\mathrm{L}^{-1}\end{array}$ & $\begin{array}{r}\mathrm{HCl}-\mathrm{Mn}^{\dagger} \\
\mathrm{ng} \\
\mathrm{L}^{-1}\end{array}$ & $\begin{array}{r}\text { DON } \\
\mu \mathrm{mol} \\
\mathrm{L}^{-1}\end{array}$ \\
\hline$n$ & 22 & 22 & 22 & 22 & 22 & 21 & 22 & 22 & 19 & 20 & 20 & 22 & 22 & 22 & 14 \\
\hline Temp. & 1 & & & & & & & & & & & & & & \\
\hline Sal. & $-0.886^{*}$ & 1 & & & & & & & & & & & & & \\
\hline $\mathrm{NH}_{4}^{+}$ & & & 1 & & & & & & & & & & & & \\
\hline $\mathrm{NO}_{3}^{-}$ & $0.727 *$ & $-0.914 *$ & & 1 & & & & & & & & & & & \\
\hline $\mathrm{NO}_{2}^{-}$ & & & & & 1 & & & & & & & & & & \\
\hline $\mathrm{NR}_{\mathrm{b}}^{2}$ & & & $0.571 *$ & & & 1 & & & & & & & & & \\
\hline DO & $0.592 *$ & $-0.458^{*}$ & & & & & 1 & & & & & & & & \\
\hline TSM & & $-0.690^{*}$ & $0.560 *$ & $0.718^{*}$ & & $0.723^{* * *}$ & & 1 & & & & & & & \\
\hline $\mathrm{CR}$ & & & & & & & & & 1 & & & & & & \\
\hline POC & $0.469^{*}$ & $-0.601 *$ & & $0.648^{*}$ & & $0.523^{*}$ & & $0.809 * *$ & & 1 & & & & & \\
\hline PON & $0.464 *$ & $-0.590 *$ & & $0.642 *$ & & $0.511^{*}$ & & $0.796^{* *}$ & & $0.999 * *$ & 1 & & & & \\
\hline $\mathrm{HCl}-\mathrm{Al}^{\dagger}$ & & $-0.477^{*}$ & & $0.430 *$ & & $0.498 *$ & & $0.555^{* *}$ & & & & 1 & & & \\
\hline $\mathrm{HCl}-\mathrm{Fe}^{\dagger}$ & & $-0.647^{*}$ & $0.575^{*}$ & $0.671 *$ & & $0.727 * *$ & & $0.971^{* *}$ & & $0.737 * *$ & $0.725^{* *} *$ & $0.668^{* *}$ & 1 & & \\
\hline $\mathrm{HCl}-\mathrm{Mn}^{\dagger}$ & & $-0.663^{*}$ & $0.570 *$ & $0.701 *$ & & $0.730^{* *}$ & $-0.079 *$ & $0.987^{* *}$ & & $0.794 * *$ & $0.783^{* *} *$ & $0.628 * *$ & $0.989 * *$ & 1 & \\
\hline DON & & & & & $0.595^{*}$ & & $0.696^{* *}$ & & & & & & & & 1 \\
\hline
\end{tabular}

$n$ is sample number. The other numbers are the Pearson's correlation coefficient of two by two parameters.

* indicates $p<0.05$ and $* *$ indicates $p<0.01$.

$\dagger \mathrm{HCl}-\mathrm{Al}$, HCl-Fe and $\mathrm{HCl}-\mathrm{Mn}$ respectively indicate reactive Al, reactive Fe and reactive Mn which were extracted from suspended particles by $1 \mathrm{~N}$ HCl. The method is described in Sect. 2.2 .

\subsubsection{Salinity}

Salinity might also be an important factor controlling the distribution of nitrifying activity and nitrifiers. Our $\mathrm{NR}_{\mathrm{b}}$ peaked at an intermediate salinity $(S=29)$ and decreased seaward to undetectable range. This pattern is similar to that reported for many estuaries (Beronsky and Nixon, 1993; Pakulski et al., 1995; Dai et al., 2008; Brion et al., 2000; Cébron et al., 2003). One possibility of high nitrifying activity at intermediate salinity is the lysis of phytoplankton, which may cause the release of organic nitrogen when it comes into contact with the saline water (Lara-Lara et al., 1990). Meanwhile, gradually elevated salinity seaward may also decrease the ammonium absorption capacity of surface sediments (Rasgaard et al., 1999) that make the suspended particles become a less favorable environment for nitrification. Accordingly, both $\beta$-AOB and AOA were no longer likely to be associated with large particles $(>3 \mu \mathrm{m})$ in the outer plume where salinity is higher and water is clearer.

\subsection{Reactive Fe as oxidant supply for nitrification in the turbid river plume}

\subsubsection{Community respiration and the oxygen demand of nitrification}

Our CR range (1.21-10.79 $\mu \mathrm{mol} \mathrm{L}^{-1} \mathrm{day}^{-1}$ ) broadly agreed with that reported for the East China Sea affected by Chang Jiang diluted water though some stations may have a CR up to $34.3 \mu \mathrm{mol} \mathrm{L}^{-1} \mathrm{day}^{-1}$ (Chen et al., 2009). We assume 
Table 2c. Correlation matrix of field-surveyed data in the outer plume of the Chang Jiang River plume.

\begin{tabular}{|c|c|c|c|c|c|c|c|c|c|c|c|c|c|c|c|}
\hline Unit & $\begin{array}{l}\text { Temp. } \\
{ }^{\circ} \mathrm{C}\end{array}$ & Sal. & $\begin{array}{c}\mathrm{NH}_{4}^{+} \\
\mu \mathrm{mol} \\
\mathrm{L}^{-1}\end{array}$ & $\begin{array}{c}\mathrm{NO}_{3}^{-} \\
\mu \mathrm{mol} \\
\mathrm{L}^{-1}\end{array}$ & $\begin{array}{c}\mathrm{NO}_{2}^{-} \\
\mu \mathrm{mol} \\
\mathrm{L}^{-1}\end{array}$ & $\begin{array}{r}\mathrm{NR}_{\mathrm{b}} \\
\mathrm{nmol}^{-1} \\
\mathrm{day}^{-1}\end{array}$ & $\begin{array}{r}\text { DO } \\
\mu \mathrm{mol} \\
\mathrm{kg}^{-1}\end{array}$ & $\begin{array}{r}\text { TSM } \\
\mathrm{mg} \\
\mathrm{L}^{-1}\end{array}$ & $\begin{array}{r}\text { CR } \\
\mu \mathrm{mol} \mathrm{L}^{-1} \\
\text { day }^{-1}\end{array}$ & $\begin{array}{r}\text { POC } \\
\mu \mathrm{g} \\
\mathrm{L}^{-1}\end{array}$ & $\begin{array}{r}\text { PON } \\
\mu g \\
L^{-1}\end{array}$ & $\begin{array}{r}\mathrm{HCl}^{-\mathrm{Al}^{\dagger}} \\
\mathrm{g} \\
\mathrm{L}^{-1}\end{array}$ & $\begin{array}{r}\mathrm{HCl}-\mathrm{Fe}^{\dagger} \\
\mathrm{mg} \\
\mathrm{L}^{-1}\end{array}$ & $\begin{array}{r}\mathrm{HCl}^{-\mathrm{Mn}^{\dagger}} \\
\mathrm{ng} \\
\mathrm{L}^{-1}\end{array}$ & $\begin{array}{r}\text { DON } \\
\mu \mathrm{mol} \\
\mathrm{L}^{-1}\end{array}$ \\
\hline$n$ & 11 & 11 & 11 & 11 & 11 & 8 & 11 & 11 & 6 & 11 & 11 & 11 & 11 & 11 & 10 \\
\hline Temp. & 1 & & & & & & & & & & & & & & \\
\hline Sal. & $-0.739^{*}$ & 1 & & & & & & & & & & & & & \\
\hline $\mathrm{NH}_{4}^{+}$ & & & 1 & & & & & & & & & & & & \\
\hline $\mathrm{NO}_{3}^{-}$ & $-0.650^{*}$ & & & 1 & & & & & & & & & & & \\
\hline $\mathrm{NO}_{2}^{-}$ & & & & & 1 & & & & & & & & & & \\
\hline $\mathrm{NR}_{\mathrm{b}}^{2}$ & $-0.737^{*}$ & & & & & 1 & & & & & & & & & \\
\hline DO & $0.864^{*}$ & $-0.922^{*}$ & & & & & 1 & & & & & & & & \\
\hline TSM & & & & & & & & 1 & & & & & & & \\
\hline $\mathrm{CR}$ & & & & & & $-0.976^{*}$ & & $0.926^{* *}$ & 1 & & & & & & \\
\hline POC & & $-0.851^{*}$ & & & & & $0.769^{* *}$ & & & 1 & & & & & \\
\hline PON & & $-0.825^{*}$ & & & & & $0.716^{*}$ & & & $0.996^{* *}$ & 1 & & & & \\
\hline $\mathrm{HCl}-\mathrm{Al}^{\dagger}$ & & & & & & & & & & & & 1 & & & \\
\hline $\mathrm{HCl}-\mathrm{Fe}^{\dagger}$ & $-0.827^{*}$ & & & & $-0.708^{*}$ & & $-0.633^{*}$ & & & & & $0.787 * *$ & 1 & & \\
\hline $\mathrm{HCl}-\mathrm{Mn}^{\dagger}$ & $-0.862^{*}$ & $0.607 *$ & & & $-0.709^{*}$ & & $-0.683^{*}$ & & & & & $0.730 *$ & $0.993^{* *}$ & 1 & \\
\hline DON & $0.675^{*}$ & $-0.913^{*}$ & $0.732 *$ & & & & $0.748^{*}$ & & & $0.759^{*}$ & $0.751^{*}$ & & & & 1 \\
\hline
\end{tabular}

$n$ is sample number. The other numbers are the Pearson's correlation coefficient of two by two parameters.

$*$ indicates $p<0.05$ and $* *$ indicates $p<0.01$.

$\dagger \mathrm{HCl}-\mathrm{Al}, \mathrm{HCl}-\mathrm{Fe}$ and $\mathrm{HCl}-\mathrm{Mn}$ respectively indicate reactive Al, reactive Fe and reactive Mn which were extracted from suspended particles by $1 \mathrm{~N} \mathrm{HCl}$. The method is described in Sect. 2.2.

Table 2d. Correlation matrix of field-surveyed data among all regions of the Chang Jiang River plume.

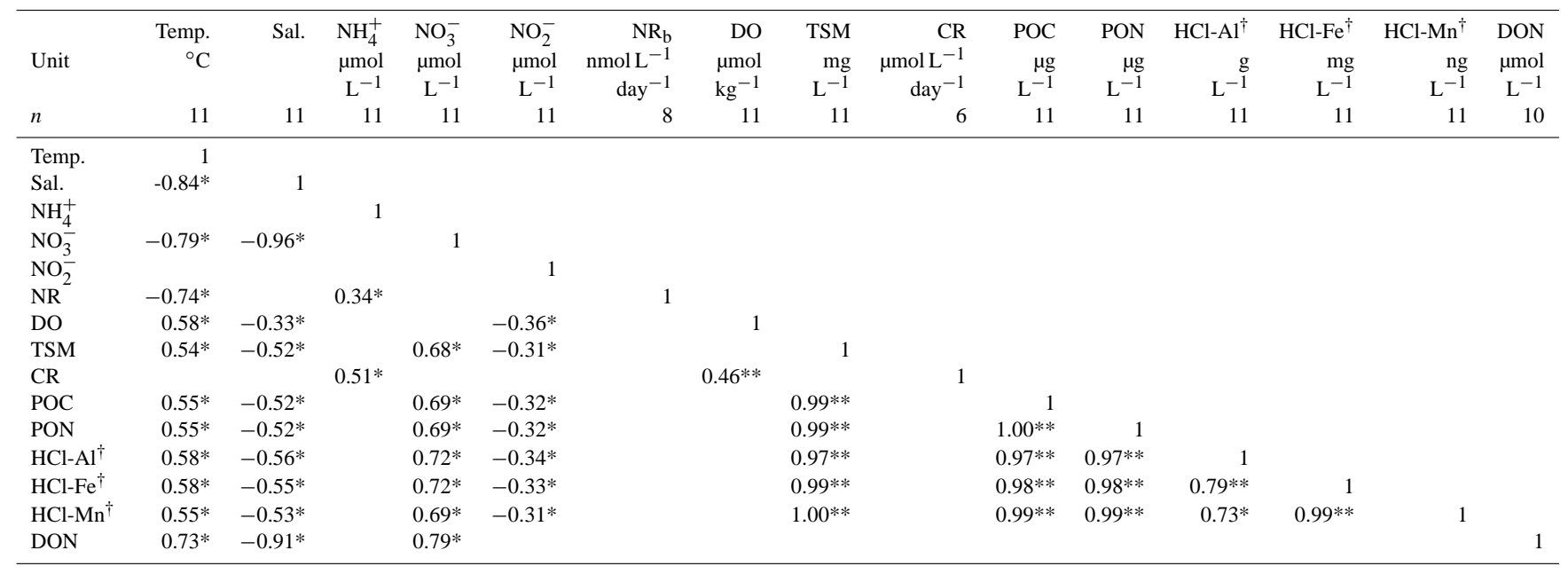

$n$ is sample number. The other numbers are the Pearson's correlation coefficient of two by two parameters.

$*$ indicates $p<0.05$ and $* *$ indicates $p<0.01$.

$\dagger \mathrm{HCl}-\mathrm{Al}$, HCl-Fe and $\mathrm{HCl}-\mathrm{Mn}$ respectively indicate reactive Al, reactive Fe and reactive Mn which were extracted from suspended particles by $1 \mathrm{~N}$ HCl. The method is described in Sect. 2.2 .

that Typhoon Muifa mixed the water column of our studied area thoroughly before our cruise and that the stratification started to reform afterward. In our cruise period the low oxygen content $(\sim 50 \%$ saturation) in the water column below $20 \mathrm{~m}$ depth thus resulted from oxygen consumption within 12 weeks or so; the oxygen consumption rate can be roughly estimated to be $\sim 10 \mu \mathrm{mol} \mathrm{L}^{-1}$ day $^{-1}$. This number is consistent with our observations.

It is well-known that oxygen is consumed during nitrification following organic matter decomposition. According to the Redfield model (Redfield et al., 1963), a total of $138 \mathrm{~mol}$ of oxygen $\left(\mathrm{O}_{2}\right)$ is required to complete the mineralization of 1 mol of organic matter (Reaction R1); of this total, $24 \mathrm{~mol}$ of oxygen are required to oxidize $16 \mathrm{~mol}$ of ammonia to nitrite
( $1 \mathrm{~mol} \mathrm{NH}_{3}$ to $1.5 \mathrm{~mol} \mathrm{O}_{2}$ in Reaction $\mathrm{R} 2$ ), and subsequently $8 \mathrm{~mol}$ of oxygen are required to oxidize $16 \mathrm{~mol}$ of nitrite to nitrate ( $1 \mathrm{~mol} \mathrm{NO}_{2}^{-}$to $0.5 \mathrm{~mol} \mathrm{O}_{2}$ in Reaction $\mathrm{R} 3$ ).

$$
\begin{aligned}
& \left(\mathrm{CH}_{2} \mathrm{O}\right)_{106}\left(\mathrm{NH}_{3}\right)_{16}\left(\mathrm{H}_{3} \mathrm{PO}_{4}\right)_{1}+138 \mathrm{O}_{2} \\
& \rightarrow 106 \mathrm{CO}_{2}+16 \mathrm{NH}_{4}^{+}+\mathrm{PO}_{4}^{3-}+106 \mathrm{H}_{2} \mathrm{O}+19 \mathrm{H}^{+}+32 \mathrm{O}_{2} \\
& \rightarrow 106 \mathrm{CO}_{2}+16 \mathrm{NO}_{3}^{-}+\mathrm{PO}_{4}^{3-}+122 \mathrm{H}_{2} \mathrm{O}+19 \mathrm{H}^{+} \\
& \mathrm{NH}_{3}+1.5 \mathrm{O}_{2} \rightarrow \mathrm{NO}_{2}^{-}+\mathrm{H}_{2} \mathrm{O}+\mathrm{H}^{+} \\
& \mathrm{NO}_{2}^{-}+0.5 \mathrm{O}_{2} \rightarrow \mathrm{NO}_{3}^{-}
\end{aligned}
$$

Therefore, the theoretical percentage of oxygen consumption via ammonia oxidation and complete nitrification can 
be derived to be $17.4 \%$ and $23.2 \%$, respectively. This estimation has been useful in some previous estuarine studies (Berounsky and Nixon, 1993; Cooper, 1984; Grundle and Juniper, 2011; Lipschultz et al., 1986). Based on the molar ratio in Reactions (R2) and (R3) and the $\mathrm{NR}_{\mathrm{b}}$ we measured, we can back-calculate the nitrification-associated oxygen demand (NOD) in the incubation experiment. Interestingly, the percentage of oxygen consumption derived from bulk nitrification ranged from 0.32 to $318 \%$. Among the NOD in total oxygen consumption, 13 data from the inner plume exceeded the Redfield model estimation of $23.2 \%$. Since our measurement cannot evidence the occurrence of the latter part of nitrification, nitrite oxidation, the relatively narrow range of nitrite in the inner plume compared to ammonium implies that nitrite oxidation was closely coupled to ammonia oxidation and left an insignificant amount of nitrite. Even if nitrite oxidation did not occur, the oxygen demand for ammonia oxidation alone calculated from Reaction (R2) and $\mathrm{NR}_{\mathrm{b}}$ still constituted $0.24-252 \%$ of $\mathrm{CR}$. The excess oxygen consumption may be caused by allochthonous ammonia participating in nitrification, which has been reported for other estuaries as well as surface sediments (Cooper, 1984; Dai et al., 2008; Pakulski et al., 1995; Seitzinger et al., 1984; Seitzinger, 1987).

Five NOD data we calculated even surpass the measured total oxygen consumption. Although this might be caused by underestimating $\mathrm{CR}$, the interesting thing is that the five data are all taken from near the turbidity maximum at stations $\mathrm{Y} 1$ and Y2. Even if nitrite oxidation did not occur, the oxygen demand for ammonia oxidation still constitutes $0.24 \sim 252 \%$ of CR. Since CR and $\mathrm{NR}_{\mathrm{b}}$ were both calculated for bulk water samples, such an abnormally high oxygen demand may imply that oxygen was not the sole electron acceptor in the nitrification reaction. To our knowledge, this phenomenon has only been documented once, in surface sediments in the Nueces estuary (Yoon and Benner, 1992).

\subsection{2 $\mathrm{Fe} / \mathrm{Mn}$ oxide as oxidant for nitrification}

Previous work has indicated that iron $\left(\mathrm{Fe}^{3+}\right)$ oxide and manganese $\left(\mathrm{Mn}^{4+}\right)$ oxide may serve as oxidants supporting nitrification in anaerobic sediments or the oxygen minimum zone (Clement et al., 2005; Hulth et al., 1999; Luther et al., 1997; Luther and Popp, 2002; Vandenabeele et al., 1995). The hypothetic reactions can be written as Reaction (R4) (Clement et al., 2005), Reaction (R5) (Luther and Popp, 2002) and Reaction (R6) (Hulth et al., 1999) in which goethite (FeOOH) and manganese oxide $\left(\mathrm{MnO}_{2}\right)$, common forms of Fe (III) and Mn (IV) in aerobic environments, were taken as oxidants in nitrification. Fe (III) cannot mediate nitrite oxidation because its redox potential is not high enough.

$$
\begin{aligned}
& \mathrm{NH}_{4}^{+}+6 \mathrm{FeOOH}+10 \mathrm{H}^{+} \rightarrow \mathrm{NO}_{2}^{-}+6 \mathrm{Fe}^{2+}+10 \mathrm{H}_{2} \mathrm{O} \\
& G^{0}=-28.9 \mathrm{~kJ} \mathrm{~mol}^{-1} \\
& \mathrm{NH}_{4}^{+}+3 \mathrm{MnO}_{2}+4 \mathrm{H}^{+} \rightarrow \mathrm{NO}_{2}^{-}+3 \mathrm{Mn}^{2+}+4 \mathrm{H}_{2} \mathrm{O} \\
& G^{0}=-353.1 \mathrm{~kJ} \mathrm{~mol}^{-1}
\end{aligned}
$$

$$
\begin{aligned}
& \mathrm{NH}_{4}^{+}+4 \mathrm{MnO}_{2}+6 \mathrm{H}^{+} \rightarrow \mathrm{NO}_{3}^{-}+4 \mathrm{Mn}^{2+}+5 \mathrm{H}_{2} \mathrm{O} \\
& G^{0}=-470.9 \mathrm{~kJ} \mathrm{~mol}^{-1}
\end{aligned}
$$

Though oxygen is a more thermodynamically favorable oxidant and sufficiently present in a water column, the microenvironment in/upon particles may be oxygen-limited due to high microbial activity. Fe (III) and Mn (IV) react as oxidants at the boundary of oxic-anoxic interface and it is very likely that they can recycle (reduce and reoxidize) hundreds of times before ultimately being buried in deep sediment (Canfield et al., 1993). However, how fast they recycle on particles is unknown. In our case, during $24 \mathrm{~h}$ incubation, it seems that reduced $\mathrm{Fe} / \mathrm{Mn}$ was not completely reoxidized by ambient oxygen or the measured CR would be higher and would not result in the current estimation of a high oxidant demand supported by non-oxygen.

The correlation between the percentage of NOD in CR versus that between $\mathrm{DO}, \mathrm{CR}$ and two alternative oxidants (reactive $\mathrm{Fe}$ and $\mathrm{Mn}$ ) is shown in Fig. 5. Over the entire study area, oxygen was sufficient along the plume with the lowest oxygen content of $58 \mu \mathrm{mol} \mathrm{L}^{-1}$ or $25.8 \%$ of saturation. Although no correlation can be seen between the estimated NOD/CR (\%) and DO, higher NOD / CR (\%) showed a tendency to occur toward DO $<200 \mu \mathrm{mol} \mathrm{L}^{-1}$. When DO $>200 \mu \mathrm{mol} \mathrm{L}^{-1}$, the Redfield model works well. On the other hand, significant linear correlations were found between the NOD/CR (\%) and reactive $\mathrm{Fe} / \mathrm{Mn}$ on particles in the inner plume (Figs. $5 \mathrm{c}$ and d), implying that the reactive $\mathrm{Fe} / \mathrm{Mn}$ of particles may participate in the nitrification process as an oxidant.

Similar to the oxygen demand estimation presented above, stoichiometric calculation was performed to evaluate whether the existing amounts of reactive $\mathrm{Fe} / \mathrm{Mn}$ were sufficient to support the oxidant demand for nitrification in our $24 \mathrm{~h}$ incubation. We consider reactive $\mathrm{Fe} / \mathrm{Mn}$ as $\mathrm{Fe}$ (III) and Mn (IV) in our estimation since the water column was aerobic. According to thermodynamically favorable Reactions (R4), (R5) and (R6), $6 \mathrm{~mol}$ of Fe (III) or $3 \mathrm{~mol}$ of $\mathrm{Mn}$ (IV) are required for $1 \mathrm{~mol}$ of ammonia to oxidize to nitrite, and $4 \mathrm{~mol}$ of $\mathrm{Mn}$ (IV) are required for $1 \mathrm{~mol}$ of ammonia to oxidize to nitrate. Therefore, we can estimate Fe (III) and Mn (IV) demand by using $\mathrm{NR}_{\mathrm{b}}$ when assuming that nitrification relied entirely on Fe (III) or Mn (IV). In Table 3, we present the observed reactive $\mathrm{Fe}$ and $\mathrm{Mn}$ in a water column versus nitrification-associated demand for $\mathrm{Fe}$ (III) and $\mathrm{Mn}$ (IV), respectively. Obviously, the observed reactive Fe is 10fold higher than what is required to support the total ammonia oxidation. However, the reactive Mn was insufficient and can only support up to $21 \%$ of the oxidant demand from ammonia to nitrate. Since nitrite accumulation was not observed in the inner plume where $\mathrm{NR}_{\mathrm{b}}$ was high, nitrite oxidation may be closely coupled to ammonia oxidation. The estimated oxidant demand of the coupled nitrite oxidation ( $25 \%$ of the oxidant demand from ammonia to nitrate) could be totally supported by dissolved oxygen. Mn (IV) might also participate 
Table 3. Estimated Fe (III) and Mn (IV) demand for nitrification and the observed concentrations along the Chang Jiang River plume.

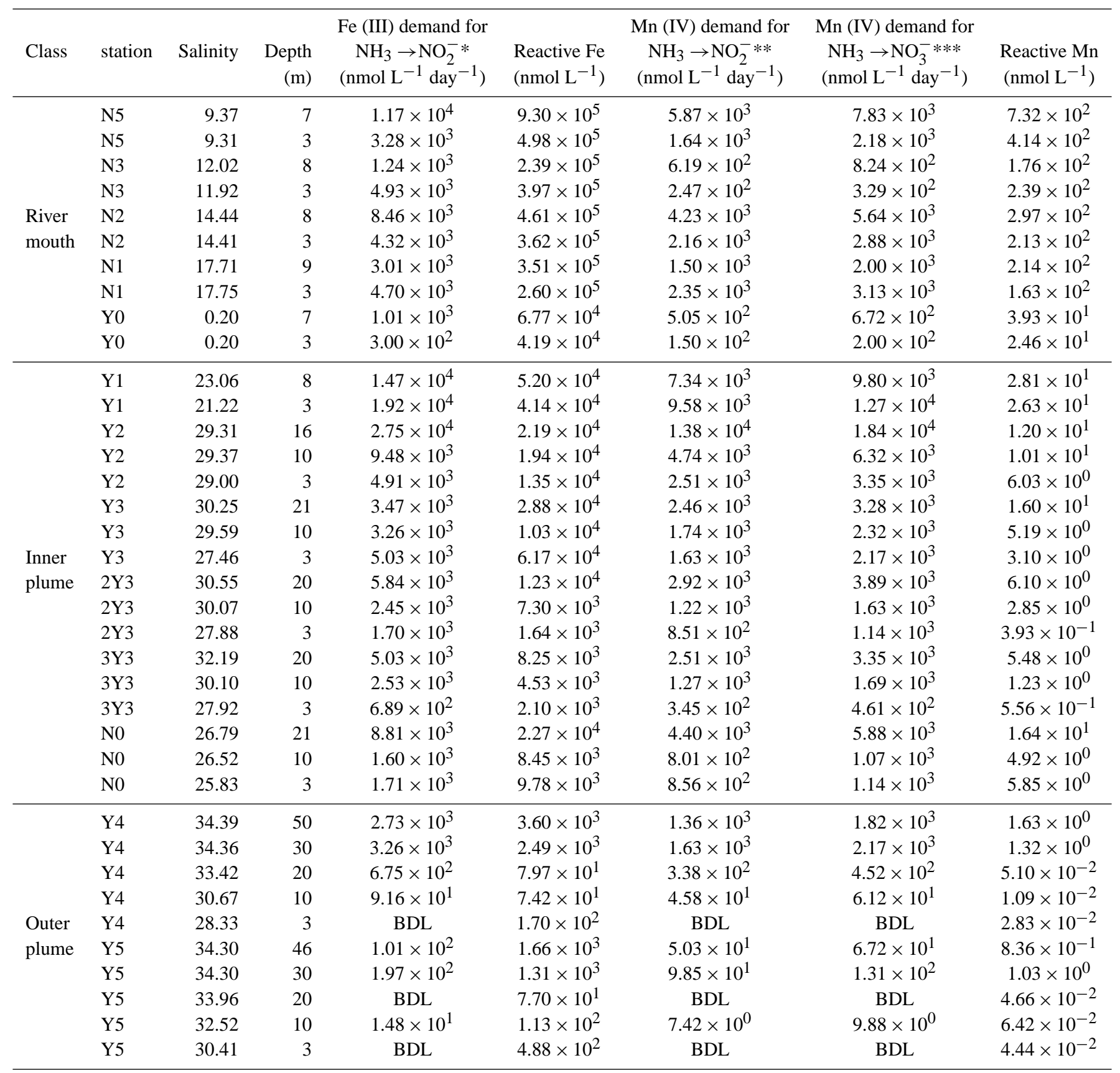

* The calculation of FeOOH demand was based on Reaction (R4) by assuming 6 mol of FeOOH are needed to oxidize 1 mol of ammonia to nitrite. *** The calculation of $\mathrm{MnO}_{2}$ demand was based on Reaction (R5) by assuming 3 mol of $\mathrm{MnO}_{2}$ are needed to oxidize 1 mol of ammonia to nitrite. *** The calculation of $\mathrm{MnO}_{2}$ demand was based Reaction (R6) by assuming 4 mol of $\mathrm{MnO}_{2}$ are needed to oxidize 1 mol of ammonia to nitrate. BDL: below detection limit; Sta.: station.

as a supplementary oxidant. The Fe/Mn reduced by nitrification was not completely reoxidized by ambient oxygen during the $24 \mathrm{~h}$ incubation. Thus, the observed oxygen consumption was not high enough to support the total oxidant demand for nitrification. Our estimation only presents the upper bound of goethite and manganese oxide demand, and we clearly know oxygen must play a role. Further investigations on the speciation of $\mathrm{Fe} / \mathrm{Mn}, \mathrm{Fe} / \mathrm{Mn}$ reduction and nitrification are needed.

According to the oxidation sequence, $\mathrm{Fe} / \mathrm{Mn}$ reduction would occur only when the redox potential was lower than that required to facilitate nitrate or nitrite reduction. Thus heterotrophic microorganisms may utilize nitrate or nitrite rather than oxygen as electron acceptors to break down 

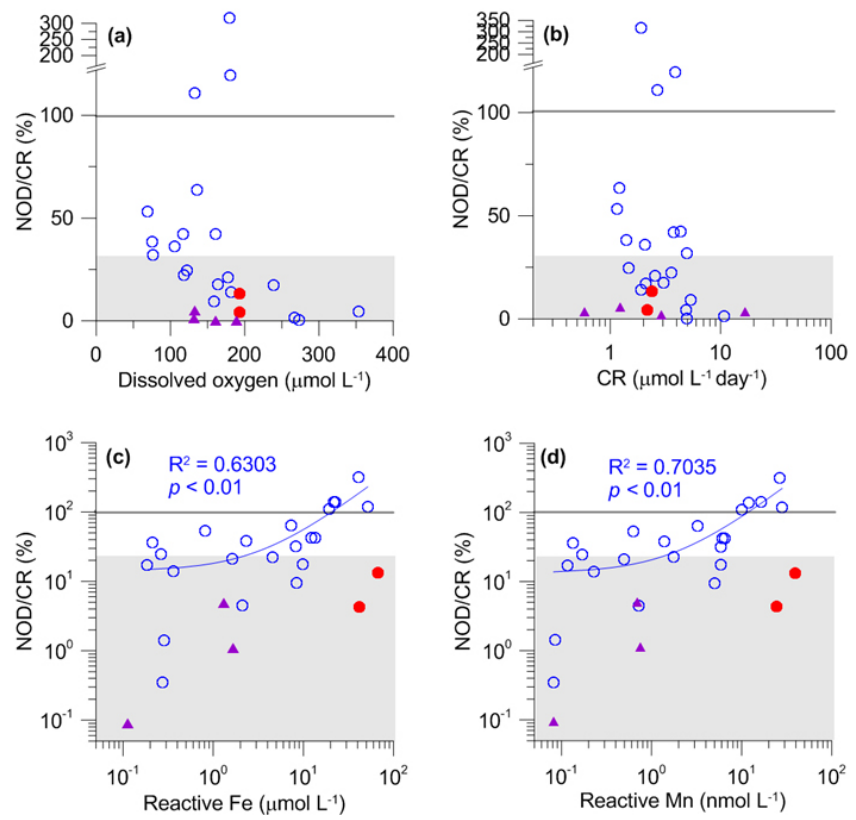

Fig. 5. Scatter plots of the percentage of nitrification-associated oxygen demand in CR against (a) dissolved oxygen, (b) community respiration rate, $(\mathbf{c})$ reactive $\mathrm{Fe}$ and (d) reactive $\mathrm{Mn}$ for the river mouth (•), the inner plume (o) and the outer plume $(\boldsymbol{\Delta})$. Data for the Qiantang river mouth and Y4 station were not included because of a lack of CR data. The shaded zone with the upper limit of $23.2 \%$ indicates the theoretical estimate by the Redfield model. The horizontal line refers to $100 \% \mathrm{CR}$. Note that both axes in (c) and (d) are in $\log _{10}$ scale.

organic matter. This means a coupled reaction between denitrification (reduction of nitrate to nitrous oxide or dinitrogen gas) or anammox (converting nitrite and ammonia to dinitrogen gas) and organic matter degradation, a common phenomenon occurring in sediment. However, the potential denitrification/anammox activity $\left(<1.6 \mathrm{nmol} \mathrm{L}^{-1} \mathrm{~d}^{-1}\right)$ in the water column measured by isotope pairing technique (Hsu and Kao, 2013) was much lower when compared to the oxygen consumption (Hsu et al., 2014). Therefore, the utilization of nitrate and nitrite as oxidants was ignorable.

The enhanced nitrification in eutrophicated estuaries has been thought to consume alkalinity to make ocean acidification worse (Dai et al., 2008). Conversely, the Fe / Mn mediated nitrification process (Eqs. 4, 5, 6) consumes protons that mitigate the releasing of $\mathrm{CO}_{2}$ into the atmosphere. Nevertheless, how various oxidants interplay with nitrification to contribute to ocean acidification remains unclear. Two important issues require more attention: (1) Fe / Mn oxide must not be overlooked in hypoxia development in such a turbid river plume; (2) since the $\mathrm{N}_{2} \mathrm{O}$ yield of ammonia oxidation might be linked to the different forms of oxidants, reactive $\mathrm{Fe} / \mathrm{Mn}$ might regulate the $\mathrm{N}_{2} \mathrm{O}$ emission in turbid coastal environments.

\section{Conclusions and implications}

The rate of nitrification and its oxygen consumption were investigated along the turbid Chang Jiang River plume. Our study suggests that ammonium concentration was one major factor in the rate of nitrification. Moreover, the amoA gene abundance and $\mathrm{NR}_{\mathrm{pf}}$ determination revealed that both archaeal and $\beta$-proteobacterial ammonia oxidizers were more likely to attach to suspended particles $(>3 \mu \mathrm{m})$. The microenvironment formed on the particle surface benefits nitrification activity in two ways. First, ammonia can be supplied by not only the ambient water but also by in situ decomposition of particulate organic matter. The latter process was evident from a significant positive correlation between TSM and $\mathrm{NR}_{\mathrm{b}}$ in turbid water. Second, under oxygen-limiting conditions, nitrification activity can be efficiently maintained by utilizing a metallic oxidant which avoids oxygen competition with heterotrophic bacteria. Stoichiometric calculations indicated that the reactive $\mathrm{Fe}$ in plume water was more than sufficient to serve as oxidant to support the full ammonia oxidation rate in our incubation experiment. We suggest that nitrification in turbid coastal water may not solely utilize oxygen; it also consumes metallic oxidants on suspended particles. In addition, the high oxygen demand of autotrophic nitrifiers also implied that a considerable fraction of CR may be attributed to nitrification. Therefore, when applying the CR in order to estimate the remineralization of organic matter, underestimation may occur because the nitrifier may consume non-oxygen oxidants, especially in turbid coastal and shelf water where NR is particularly high.

Acknowledgements. We are grateful to Shuen-Hsin Lin and Yi-Tang Huang for helping with the ICP-MS analysis of particulate metal content and Zhouling Zhang for assisting with the on-deck nutrient measurement. We also thank the editors Christophe Rabouille and Florian Moeller, Xinghui Xia and three anonymous reviewers for providing helpful comments that improved the manuscript. This research was supported by the National Science Council, Taiwan, and the National Natural Science Foundation of China (NSFC 41176059, 2009CB421200).

Edited by: C. Rabouille

\section{References}

Andersson, M. G. I., Brion, N., and Middelburg, J. J.: Comparison of nitrifier activity versus growth in the Scheldt estuary - a turbid, tidal estuary in northern Europe, Aquat. Microb. Ecol., 42, 149158, 2006.

Bano, N. and Hollibaugh, J. T.: Diversity and distribution of DNA sequences with affinity to ammonia-oxidizing bacteria of the beta subdivision of the class Proteobacteria in the Arctic Ocean, Appl. Environ. Microbiol., 66, 1960-1969, 2000.

Belser, L. W.: Population Ecology of Nitrifying Bacteria, Annu. Rev. Microbiol., 33, 309-333, 1979. 
Berounsky, V. M. and Nixon, S. W.: Rates of Nitrification Along an Estuarine Gradient in Narragansett Bay, Estuaries, 16, 718-730, 1993.

Bianchi, M., Feliatra, and Lefevre, D.: Regulation of nitrification in the land-ocean contact area of the Rhone River plume (NW Mediterranean), Aquat. Microb. Ecol., 18, 301-312, 1999.

Brion, N., Billen, G., Guezennec, L., and Ficht, A.: Distribution of nitrifying activity in the Seine River (France) from Paris to the estuary, Estuaries, 23, 669-682, 2000.

Bronk, D. A., Lomas, M. W., Glibert, P. M., Schukert, K. J., and Sanderson, M. P.: Total dissolved nitrogen analysis: comparisons between the persulfate, UV and high temperature oxidation methods, Mar. Chem., 69, 163-178, 2000.

Casciotti, K. L., Sigman, D. M., Hastings, M. G., Bohlke, J. K., and Hilkert, A.: Measurement of the oxygen isotopic composition of nitrate in seawater and freshwater using the denitrifier method, Anal. Chem., 74, 4905-4912, 2002.

Cebron, A., Berthe, T., and Garnier, J.: Nitrification and nitrifying bacteria in the lower Seine River and estuary (France), Appl. Environ. Microbiol., 69, 7091-7100, 2003.

Chai, C., Yu, Z. M., Shen, Z. L., Song, X. X., Cao, X. H., and Yao, Y.: Nutrient characteristics in the Yangtze River Estuary and the adjacent East China Sea before and after impoundment of the Three Gorges Dam, Sci. Total Environ., 407, 4687-4695, 2009.

Chen, C. C., Shiah, F. K., Chiang, K. P., Gong, G. C., and Kemp, W. M.: Effects of the Changjiang (Yangtze) River discharge on planktonic community respiration in the East China Sea, J. Geophys. Res.-Oceans, 114, C03005, doi:10.1029/2008JC004891, 2009.

Chen, Z., Li, J., Shen, H., and Wang, Z.: Changjiang of China: historical analysis of discharge variability and sediment flux, Geomorphology, 41, 77-91, 2001.

Clement, J. C., Shrestha, J., Ehrenfeld, J. G., and Jaffe, P. R.: Ammonium oxidation coupled to dissimilatory reduction of iron under anaerobic conditions in wetland soils, Soil Biol. Biochem., 37, 2323-2328, 2005.

Cooper, A. B.: Activities of Benthic Nitrifiers in Streams and Their Role in Oxygen-Consumption, Microbiol. Ecol., 10, 317-334, 1984.

Dai, M., Wang, L., Guo, X., Zhai, W., Li, Q., He, B., and Kao, S.-J.: Nitrification and inorganic nitrogen distribution in a large perturbed river/estuarine system: the Pearl River Estuary, China, Biogeosciences, 5, 1227-1244, doi:10.5194/bg-5-12272008, 2008.

Dai, Z. J., Du, J. Z., Zhang, X. L., Su, N., and Li, J. F.: Variation of Riverine Material Loads and Environmental Consequences on the Changjiang (Yangtze) Estuary in Recent Decades (19552008), Environ. Sci. Technol., 45, 223-227, 2011.

Freitag, T. E. and Prosser, J. I.: Differences between betaproteobacterial ammonia-oxidizing communities in marine sediments and those in overlying water, Appl. Environ. Microbiol., 70, 37893793, 2004.

Fussel, J., Lam, P., Lavik, G., Jensen, M. M., Holtappels, M., Gunter, M., and Kuypers, M. M.: Nitrite oxidation in the Namibian oxygen minimum zone, Isme J., 6, 1200-1209, 2012.

Galand, P. E., Lovejoy, C., Pouliot, J., and Vincent, W. F.: Heterogeneous archaeal communities in the particle-rich environment of an arctic shelf ecosystem, J. Mar. Syst., 74, 774-782, 2008.
Galloway, J. N., Dentener, F. J., Capone, D. G., Boyer, E. W., Howarth, R. W., Seitzinger, S. P., Asner, G. P., Cleveland, C. C., Green, P. A., Holland, E. A., Karl, D. M., Michaels, A. F., Porter, J. H., Townsend, A. R., and Vorosmarty, C. J.: Nitrogen cycles: past, present, and future, Biogeochemistry, 70, 153-226, 2004.

Garnier, J., Cebron, A., Tallec, G., Billen, G., Sebilo, M., and Martinez, A.: Nitrogen behaviour and nitrous oxide emission in the tidal Seine River estuary (France) as influenced by human activities in the upstream watershed, Biogeochemistry, 77, 305-326, 2006.

Gazeau, F., Gattuso, J. P., Middelburg, J. J., Brion, N., Schiettecatte, L. S., Frankignoulle, M., and Borges, A. V.: Planktonic and whole system metabolism in a nutrient-rich estuary (the Scheldt estuary), Estuaries, 28, 868-883, 2005.

Grundle, D. S., and Juniper, S. K.: Nitrification from the lower euphotic zone to the sub-oxic waters of a highly productive British Columbia fjord, Mar. Chem., 126, 173-181, 2011.

Gunnarsson, J., Bjork, M., Gilek, M., Granberg, M., and Rosenberg, R.: Effects of eutrophication on contaminant cycling in marine benthic systems, Ambio, 29, 252-259, 2000.

Helder, W. and Devries, R. T. P.: Estuarine Nitrite Maxima and Nitrifying Bacteria (Ems-Dollard Estuary), Neth. J. Sea Res., 17, $1-18,1983$.

Hollibaugh, J. T., Bano, N., and Ducklow, H. W.: Widespread distribution in polar oceans of a 16S rRNA gene sequence with affinity to Nitrosospira-like ammonia-oxidizing bacteria, Appl. Environ. Microbiol., 68, 1478-1484, 2002.

Howarth, R. W. and Marino, R.: Nitrogen as the limiting nutrient for eutrophication in coastal marine ecosystems: Evolving views over three decades, Limnol. Oceanogr., 51, 364-376, 2006.

Hsu, S. C., Liu, S. C., Lin, C. Y., Hsu, R. T., Huang, Y. T., and Chen, Y. W.: Metal compositions of $\mathrm{PM}_{10}$ and $\mathrm{PM}_{2.5}$ aerosols in Taipei during spring, 2002, Terr. Atmos. Ocean. Sci., 15, 925948, 2004.

Hu, A. Y., Jiao, N. Z., and Zhang, C. L. L.: Community Structure and Function of Planktonic Crenarchaeota: Changes with Depth in the South China Sea, Microbiol. Ecol., 62, 549-563, 2011.

$\mathrm{Hu}$, X. P. and Cai, W. J.: An assessment of ocean margin anaerobic processes on oceanic alkalinity budget, Global Biogeochem. Cy., 25, GB3003, doi:10.1029/2010GB003859, 2011.

Huertadiaz, M. A. and Morse, J. W.: A Quantitative Method for Determination of Trace-Metal Concentrations in Sedimentary Pyrite, Mar. Chem., 29, 119-144, 1990.

Hulth, S., Aller, R. C., and Gilbert, F.: Coupled anoxic nitrification manganese reduction in marine sediments, Geochim. Cosmochim. Ac., 63, 49-66, 1999.

Kao, S. J., Horng, C. S., Roberts, A. P., and Liu, K. K.: Carbonsulfur-iron relationships in sedimentary rocks from southwestern Taiwan: influence of geochemical environment on greigite and pyrrhotite formation, Chem. Geol., 203, 153-168, 2004.

Kao, S. J., Yang, J. Y. T., Liu, K. K., Dai, M. H., Chou, W. C., Lin, H. L., and Ren, H. J.: Isotope constraints on particulate nitrogen source and dynamics in the upper water column of the oligotrophic South China Sea, Global Biogeochem. Cy., 26, GB2033, doi:10.1029/2011GB004091, 2012.

Knapp, A. N., Sigman, D. M., Lipschultz, F., Kustka, A. B., and Capone, D. G.: Interbasin isotopic correspondence between upper-ocean bulk DON and subsurface nitrate and its implica- 
tions for marine nitrogen cycling, Global Biogeochem. Cy., 25, GB4004, doi:10.1029/2010GB003878, 2011.

Lara-Lara, J. R., Frey, B. E., and Small, L. F.: Primary Production in the Columbia River Estuary I. Spatial and Temporal Variability of Properties!, Pacific Sci., 44, 17-37, 1990.

Lipschultz, F., Wofsy, S. C., and Fox, L. E.: Nitrogen-Metabolism of the Eutrophic Delaware River Ecosystem, Limnol. Oceanogr., 31, 701-716, 1986.

Luther, G. W. and Popp, J. I.: Kinetics of the abiotic reduction of polymeric manganese dioxide by nitrite: An anaerobic nitrification reaction, Aquat. Geochem., 8, 15-36, 2002.

Luther, G. W., Sundby, B., Lewis, B. L., Brendel, P. J., and Silverberg, N.: Interactions of manganese with the nitrogen cycle: Alternative pathways to dinitrogen, Geochim. Cosmochim. Ac. 61, 4043-4052, 1997.

Mackey, K. R. M., Bristow, L., Parks, D. R., Altabet, M. A., Post, A. F., and Paytan, A.: The influence of light on nitrogen cycling and the primary nitrite maximum in a seasonally stratified sea, Progr. Oceanogr., 91, 545-560, 2011.

Merbt, S. N., Stahl, D. A., Casamayor, E. O., Marti, E., Nicol, G. W., and Prosser, J. I.: Differential photoinhibition of bacterial and archaeal ammonia oxidation, FEMS Microbiol. Lett., 327, 4146, 2012.

Milliman, J. D., and Syvitski, J. P. M.: Geomorphic Tectonic Control of Sediment Discharge to the Ocean - the Importance of Small Mountainous Rivers, J Geol, 100, 525-544, 1992.

Ning, X., Lin, C., Su, J., Liu, C., Hao, Q., and Le, F.: Longterm changes of dissolved oxygen, hypoxia, and the responses of the ecosystems in the East China Sea from 1975 to 1995, J. Oceanogr., 67, 59-75, 2011.

Off, S., Alawi, M., and Spieck, E.: Enrichment and Physiological Characterization of a Novel Nitrospira-Like Bacterium Obtained from a Marine Sponge, Appl. Environ. Microbiol., 76, 46404646, 2010

O'Mullan, G. D. and Ward, B. B.: Relationship of temporal and spatial variabilities of ammonia-oxidizing bacteria to nitrification rates in Monterey Bay, California, Appl. Environ. Microbiol., 71, 697-705, 2005.

Owens, N. J. P.: Estuarine Nitrification - a Naturally-Occurring Fluidized-Bed Reaction, Estuar. Coast Shelf. S., 22, 31-44, 1986.

Pai, S. C., Tsau, Y. J., and Yang, T. I.: pH and buffering capacity problems involved in the determination of ammonia in saline water using the indophenol blue spectrophotometric method, Anal. Chim. Acta, 434, 209-216, 2001.

Pakulski, J. D., Benner, R., Amon, R., Eadie, B., and Whitledge, T.: Community Metabolism and Nutrient Cycling in the Mississippi River Plume - Evidence for Intense Nitrification at Intermediate Salinities, Mar. Ecol.-Prog. Ser., 117, 207-218, 1995.

Phillips, C. J., Smith, Z., Embley, T. M., and Prosser, J. I.: Phylogenetic differences between particle-associated and planktonic ammonia-oxidizing bacteria of the beta subdivision of the class Proteobacteria in the northwestern Mediterranean Sea, Appl. Environ. Microbiol., 65, 779-786, 1999.

Rabalais, N. N., Turner, R. E., and Wiseman, W. J.: Gulf of Mexico hypoxia, aka "The dead zone", Annu. Rev. Ecol. Syst., 33, 235 263, 2002

Ravishankara, A. R., Daniel, J. S., and Portmann, R. W.: Nitrous Oxide (N2O): The Dominant Ozone-Depleting Substance Emitted in the 21st Century, Science, 326, 123-125, 2009.
Redfield, A. C., Ketchum, B. H., and Richards, F. A.: The Influence of Organism on the Composition of Sea Water, in: The sea, edited by: Hill, M. N., Wiley-Interscience, New York, 26-77, 1963.

Rysgaard, S., Thastum, P., Dalsgaard, T., Christensen, P. B., and Sloth, N. P.: Effects of salinity on $\mathrm{NH}_{4}^{+}$adsorption capacity, nitrification, and denitrification in Danish estuarine sediments, Estuaries, 22, 21-30, 1999.

Santoro, A. E., Sakamoto, C. M., Smith, J. M., Plant, J. N., Gehman, A. L., Worden, A. Z., Johnson, K. S., Francis, C. A., and Casciotti, K. L.: Measurements of nitrite production in and around the primary nitrite maximum in the central California Current, Biogeosciences, 10, 7395-7410, doi:10.5194/bg-10-7395-2013, 2013.

Seitzinger, S. P., Nixon, S. W., and Pilson, M. E. Q.: Denitrification and Nitrous-Oxide Production in a Coastal Marine Ecosystem, Limnol. Oceanogr., 29, 73-83, 1984.

Seitzinger, S. P.: Nitrogen Biogeochemistry in an Unpolluted Estuary - the Importance of Benthic Denitrification, Mar. Ecol.-Prog. Ser., 41, 177-186, 1987.

Sigman, D. M., Casciotti, K. L., Andreani, M., Barford, C. Galanter, M., and Bohlke, J. K.: A bacterial method for the nitrogen isotopic analysis of nitrate in seawater and freshwater, Anal. Chem., 73, 4145-4153, 2001.

Smith, V. H., Joye, S. B., and Howarth, R. W.: Eutrophication of freshwater and marine ecosystems, Limnol. Oceanogr., 51, 351$355,2006$.

Somville, M.: Use of nitrifying activity measurements for describing the effect of salinity on nitrification in the Scheldt Estuary, Appl. Environ. Microb., 47, 424-426, 1984.

Syvitski, J. P. M., Vorosmarty, C. J., Kettner, A. J., and Green, P.: Impact of humans on the flux of terrestrial sediment to the global coastal ocean, Science, 308, 376-380, 2005.

Tseng, Y.-F., Lin, J., Dai, M., and Kao, S.-J.: Joint effect of freshwater plume and coastal upwelling on phytoplankton growth off the Changjiang River, Biogeosciences, 11, 409-423, doi:10.5194/bg-11-409-2014, 2014.

Vandenabeele, J., Vandewoestyne, M., Houwen, F., Germonpre, R., Vandesande, D., and Verstraete, W.: Role of Autotrophic Nitrifiers in Biological Manganese Removal from Groundwater Containing Manganese and Ammonium, Microbiol. Ecol., 29, 8398, 1995

Wang, B. D.: Hydromorphological mechanisms leading to hypoxia off the Changjiang estuary, Mar. Environ. Res., 67, 53-58, 2009.

Wang, B. D., Wei, Q. S., Chen, J. F., and Xie, L. P.: Annual cycle of hypoxia off the Changjiang (Yangtze River) Estuary, Mar. Environ. Res., 77, 1-5, 2012.

Wang, H. Y., Shen, Z. Y., Guo, X. J., Niu, J. F., and Kang, B.: Ammonia adsorption and nitritation in sediments derived from the Three Gorges Reservoir, China, Environ. Earth Sci., 60, 1653 1660, 2010.

Wei, H., He, Y. C., Li, Q. J., Liu, Z. Y., and Wang, H. T.: Summer hypoxia adjacent to the Changjiang Estuary, J. Mar. Syst., 67, 292-303, 2007.

Woebken, D., Fuchs, B. M., Kuypers, M. M. M., and Amann, R.: Potential interactions of particle-associated anammox bacteria with bacterial and archaeal partners in the Namibian upwelling system, Appl. Environ. Microbiol., 73, 4648-4657, 2007.

Wuchter, C., Abbas, B., Coolen, M. J. L., Herfort, L., van Bleijswijk, J., Timmers, P., Strous, M., Teira, E., Herndl, G. J., Mid- 
delburg, J. J., Schouten, S., and Damste, J. S. S.: Archaeal nitrification in the ocean, P. Natl. Acad. Sci. USA, 103, 12317-12322, 2006.

Xia, X. H., Yang, Z. F., and Zhang, X. Q.: Effect of SuspendedSediment Concentration on Nitrification in River Water: Importance of Suspended Sediment-Water Interface, Environ. Sci. Technol., 43, 3681-3687, 2009.

Yoon, W. B. and Benner, R.: Denitrification and OxygenConsumption in Sediments of 2 South Texas Estuaries, Mar. Ecol.-Prog. Ser., 90, 157-167, 1992.
Zhou, F., Xuan, J. L., Ni, X. B., and Huang, D. J.: A preliminary study of variations of the Changjiang Diluted Water between August of 1999 and 2006, Acta Oceanol. Sin., 28, 1-11, 2009.

Zhu, Z. Y., Zhang, J., Wu, Y., Zhang, Y. Y., Lin, J., and Liu, S. M.: Hypoxia off the Changjiang (Yangtze River) Estuary: Oxygen depletion and organic matter decomposition, Mar. Chem., 125, 108-116, 2011. 